\title{
INVENTÁRIO QUALI-QUANTITATIVO DA ARBORIZAÇÃO VIÁRIA DA ESTÂNCIA DE ÁGUAS DE SÃO PEDRO-SP
}

\section{SilvanA Bortoleto}

\author{
Dissertação apresentada à Escola \\ Superior de Agricultura "Luiz de \\ Queiroz", Universidade de São Paulo, \\ para obtenção do título de Mestre em \\ Agronomia, Área de Concentração: \\ Fitotecnia.
}

P I R A C I C A B A

Estado de São Paulo - Brasil

Maio - 2004 


\section{INVENTÁRIO QUALI-QUANTITATIVO DA ARBORIZAÇÃO VIÁRIA DA ESTÂNCIA DE ÁGUAS DE SÃO PEDRO-SP}

\section{Silvana Bortoleto}

Engenheiro Agrônomo

Orientador: Prof. Dr. ROBERVAL DE CÁSSIA SALVADOR RIBEIRO

Dissertação apresentada à Escola Superior de Agricultura "Luiz de Queiroz", Universidade de São Paulo, para obtenção do título de Mestre em Agronomia, Área de Concentração: Fitotecnia.

P I R A C I C A B A

Estado de São Paulo - Brasil

Maio - 2004 


\section{Dados Internacionais de Catalogação na Publicação (CIP) DIVISÃO DE BIBLIOTECA E DOCUMENTAÇÃO - ESALQ/USP}

\section{Bortoleto, Silvana}

Inventário quali-quantitativo da arborização viária da Estância de Águas de São

Pedro - SP / Silvana Bortoleto. - - Piracicaba, 2004.

85 p. : il.

Dissertação (mestrado) - - Escola Superior de Agricultura Luiz de Queiroz, 2004.

Bibliografia.

1. Arborização 2. Inventário florestal 3. Ruas e avenidas 4. Vias I. Título

CDD 715.2

"Permitida a cópia total ou parcial deste documento, desde que citada a fonte - O autor" 
Aos meus pais

José Luiz Bortoleto

e

Antonia Maria Nicoleti Bortoleto

DEDICO. 


\section{AGRADECIMENTOS}

À todos os Anjos e Santos que intercederam por mim junto a Jesus Cristo.

Aos meus pais pela oportunidade, incentivo e carinho; ao meu primo Miguel pela companhia a eles.

À toda minha família que me recebeu nesta cidade, entre tias, primas e avós. Em especial à tia Deolinda, pelo acolhimento durante tantos meses de hospedagem, em tão agradável companhia e à tia Gina, pelo carinho e cuidados em todo o tempo.

Às minhas amigas de convívio diário e às minhas amigas de longe, pela alegria compartilhada e companheirismo. Não caberia citar todas, dentre elas, Cecília, Katota, Loca, Sílvia, Virgínia, Magali, Patrícia, Gija, Picolina, Santa, Phynna, Curtiça, Smorf, Potira e Adriana.

Ao Alexandre Rodrigues da Silva pelos momentos de ternura.

À tia Zéle pela atenção nas correções gramaticais.

Aos meus amigos de profissão: Camila Abrahao, Carlos Umberto Rossi Junior, Carolina dos Santos Amaral, Danielle Angeloni Oldemburgo, Danilo José Libardi, Edgar Ono Torre, Giovanna Alves Sindair, Larissa Leite Tosetti, Leticia Mika Tiba, Mariana Nogueira Pavan, Marina Shinkai Gentil, Marzo Zoca, Monica Mayumi Sato, Otávio Augusto Faria, Rafael Campagnol, Ricardo Massumoto Masuda e Rodrigo Zilo; que possibilitaram a realização dessa dissertação através de levantamentos a campo e digitação de dados, em trabalho voluntário e de imenso valor.

À Daniela Medeiros pela contribuição.

Ao Grupo Plantarte-Paisagismo pelo incentivo, pelas oportunidades e amizades proporcionadas. 
À Comissão do Curso de Pós-Graduação em Fitotecnia pela oportunidade de realização do curso de mestrado.

Ao Prof. Dr. Durval Dourado Neto e ao Prof. Dr. Pedro Jacob Christoffoleti pela confiança.

Aos professores, funcionários e secretárias de departamento de Produção Vegetal, pelo agradável convívio e ajudas.

Aos funcionários da Produção Vegetal, Erreinaldo Donizeti Bortolazzo e Osvaldo Mendes que se disponibilizaram em tempo preciso.

À secretária Luciane Lopes, pela amizade e todo seu esforço em auxílios constantes.

Ao Jefferson Lordello Polizel pela atenção, inestimável ajuda, empréstimo de materiais e computador.

Ao Ricardo Rabatshi pela valiosa ajuda na formatação.

À Eliana Maria Garcia e à Silvia Maria Ziusly pela rápida verificação final.

Ao Prof. Dr. Roberval de Cássia Salvador Ribeiro pela orientação, contatos com a Prefeitura da Estância de Águas de São Pedro e empenho nas correções finais.

À Prof. Dra Ana Maria Pereira L. Lima, pelo acompanhamento em todo o decorrer do curso e constantes ajudas.

Ao Prof. Dr. Demóstenes Ferreira da Silva Filho pela co-orientação, paciência entusiasmo, incentivo, empréstimo de material, pelas horas cedidas e por todo o apoio recebido.

Ao Prof. Dr. Vinícius Castro Souza e ao Eng ${ }^{\circ}$ Florestal Marcelo Antonio de Pinho Ferreira pela criteriosa identificação do material botânico e pelo apoio nas correções.

À Capes pela concessão da bolsa de estudos, viabilizando a dissertação.

À Prefeitura Municipal da Estância de Águas de São Pedro em especial ao exprefeito Luiz Antonio De Mitri Filho e à secretária Eliane Esteves Muller, pelo incentivo e apoio. 


\section{SUMÁRIO}

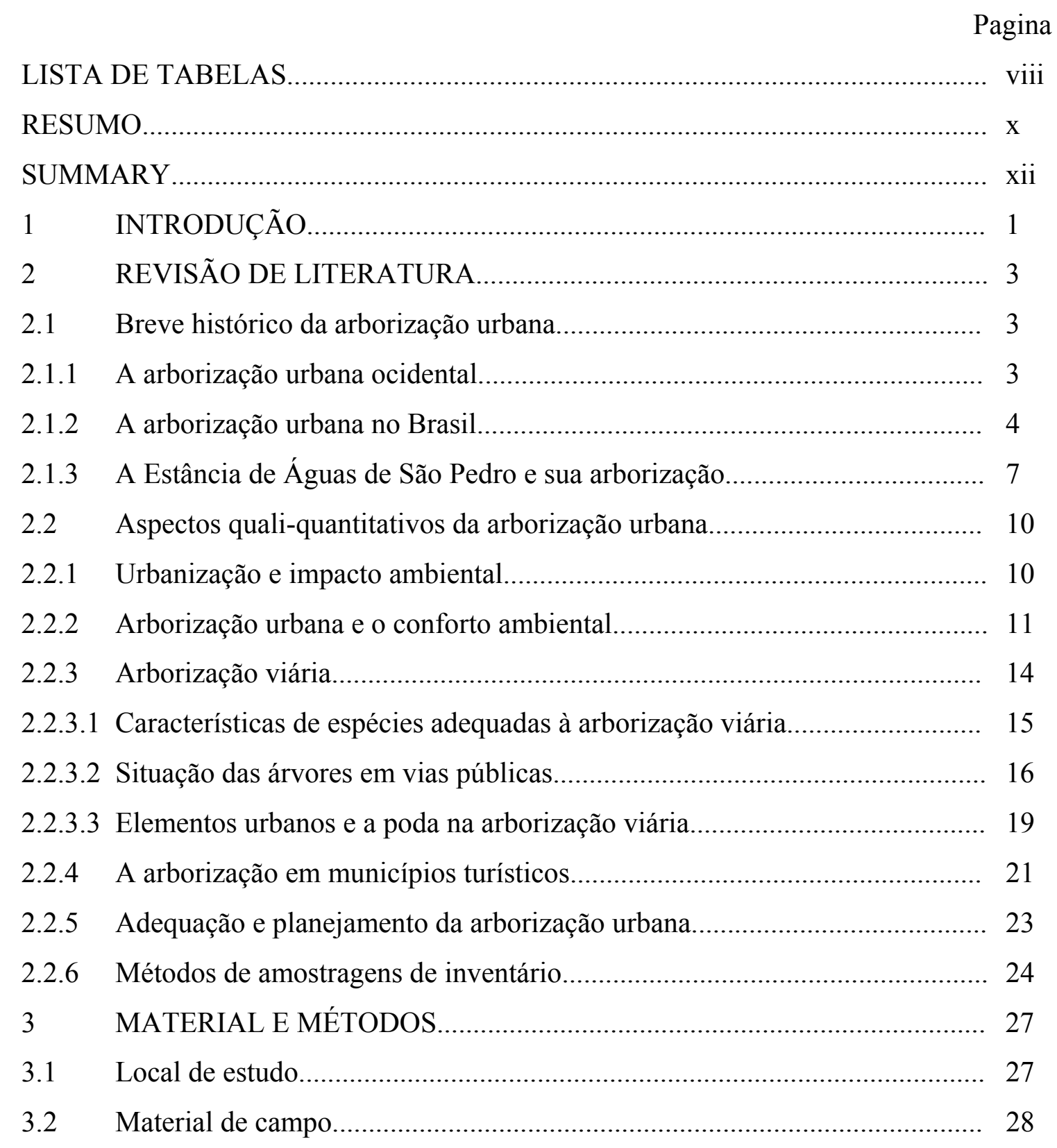


3.3 Levantamento de informações................................................................... 28

3.3.1 Localização e identificação......................................................................... 29

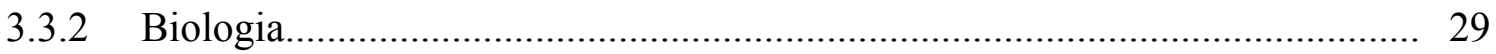

3.3.3 Entorno e interferências................................................................... 31

3.3.4 Definições de ações................................................................................... 32

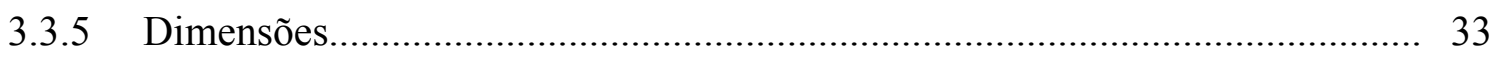

$3.4 \quad$ Análise dos dados.............................................................................. 33

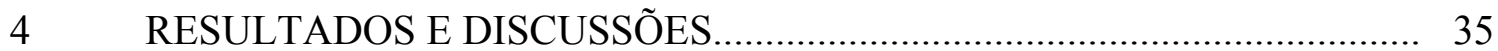

4.1 Composição e distribuição das espécies........................................................... 35

4.2 Situação geral........................................................................................ 53

4.3 Arborização e elementos urbanos.................................................................. 57

4.3.1 Calçamentos e raízes............................................................................... 59

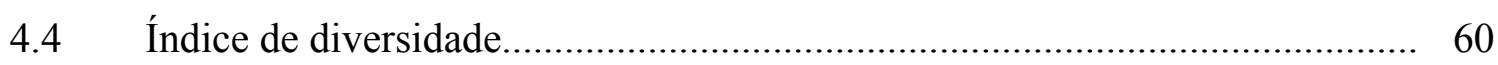

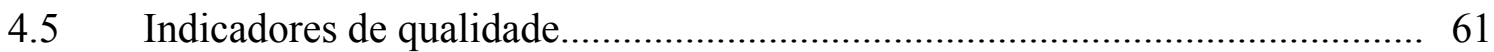

4.6 Ações executadas e ações recomendadas........................................................ 63

4.7 Outras informações relevantes.................................................................... 64

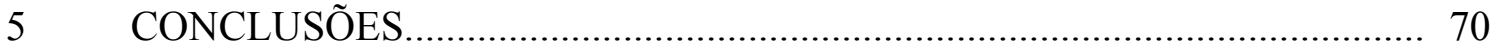

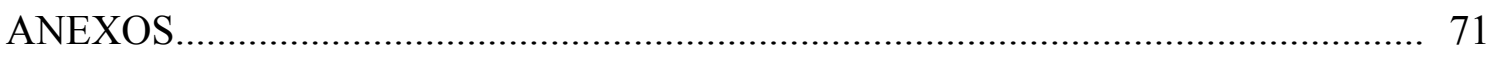

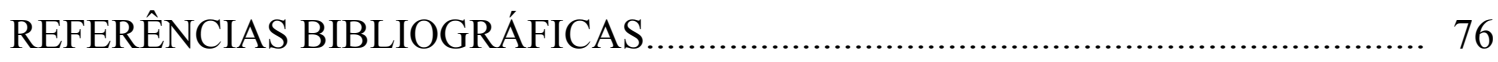




\section{LISTA DE TABELAS}

Página

1 Distribuição quantitativa de cada espécie encontrada na arborização viária da Estância de Águas de São Pedro, segundo o nome comum, o nome científico, total de indivíduos e freqüência .......................................................

2 Distribuição quantitativa dos gêneros na arborização viária da Estância de Águas de São Pedro-SP.

3 Distribuição quantitativa das famílias na arborização viária da Estância de Águas de São Pedro-SP.

4 Número total e índice de indivíduos por quilômetro de cada via pública da Estância de Águas de São Pedro, com respectivos comprimentos

5 Distribuição das espécies de maior freqüência na arborização viária da Estância Turística de Águas de São Pedro-SP com altura inferior a 1 metro...

6 Distribuição das espécies de maior freqüência na arborização viária da Estância Turística de Águas de São Pedro-SP com altura inferior a 2 metros..

7 Distribuição das espécies de maior freqüência na arborização viária da Estância Turística de Águas de São Pedro-SP com altura superior a 2 metros.

8 Distribuição das espécies de maior freqüência na arborização viária da Estância Turística de Águas de São Pedro-SP em ótimas condições gerais..... 56

9 Distribuição das espécies na arborização viária da Estância Turística de Águas de São Pedro-SP com lesão grave

10 Distribuição das espécies de maior freqüência na arborização viária da Estância Turística de Águas de São Pedro-SP, com contato potencial de alcance da fiação aérea 
11 Distribuição das espécies de maior freqüência na arborização viária da Estância Turística de Águas de São Pedro-SP, com contato atual com a fiação

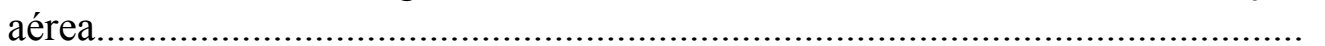

12 Distribuição das espécies de maior freqüência na arborização viária da Estância Turística de Águas de São Pedro-SP, que apresentam afloramento

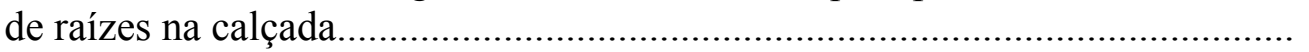

13 Distribuição das espécies com presença de ninhos na arborização viária da Estância Turística de Águas de São Pedro-SP.

14 Distribuição das espécies de maior freqüência com presença de líquens na arborização viária da Estância Turística de Águas de São Pedro-SP.

15 Distribuição das espécies com recomendação de substituição na arborização viária da Estância Turística de Águas de São Pedro-SP

16 Relação das espécies na arborização viária da Estância Turística de Águas de São Pedro-SP, com sua procedência, hábito de crescimento e época de florescimento. 


\title{
INVENTÁRIO QUALI-QUANTITATIVO DA ARBORIZAÇÃO VIÁRIA DA ESTÂNCIA DE ÁGUAS DE SÃO PEDRO-SP
}

\author{
Autora: SILVANA BORTOLETO \\ Orientador: Prof. Dr. ROBERVAL DE CÁSSIA SALVADOR RIBEIRO
}

\section{RESUMO}

A arborização viária possui importante papel na manutenção do equilíbrio físico-ambiental das cidades e pode ser considerada um indicativo de qualidade de vida. Porém, a falta de planejamento em sua implantação e manutenção acaba por prejudicar sua eficiência. Também o não conhecimento do patrimônio arbóreo e arbustivo presente e das suas respectivas condições, dificultam a tomadas de decisões corretas. O presente trabalho ocupa-se, do levantamento quali-quantitativo da arborização viária da Estância de Águas de São Pedro-SP. Para tanto, foi adotado o método de inventário do tipo censo, ou seja, foram inventariados todos os indivíduos arbóreos e arbustivos contidos nas vias públicas. Foram levantados um total de 3654 indivíduos, perfazendo 161 espécies, 126 gêneros e 54 famílias. Desse total, $61,33 \%$ das espécies são exóticas e $38,67 \%$ são nativas, distribuídas, segundo hábito de crescimento em 70,85\% arbóreas, 19,90\% arbustivas, 6,05\% palmeiras e 3,20\% coníferas. O índice de diversidade de ShannonWiener calculado é de 3,90. Na Estância de Águas de São Pedro há apenas uma discreta predominância da Caesalpinia peltophoroides (sibipiruna) que representa 13,36\% da arborização viária. O índice médio de indivíduos por quilômetro de rua percorrida é 
de 130, considerado alto, embora o hábito de crescimento não tenha sido considerado neste cálculo. Existe uma tendência ao plantio de arbustos, especialmente em anos mais recentes, que deve ser revertida. São sugeridas indicações de manejo, como novos plantios, substituições, adequação das podas e na condução de mudas e incremento do plantio de espécies arbóreas nativas em detrimento das arbustivas. Conclui-se que há a necessidade de implementação de um plano diretor que contemple a arborização, para que se melhore sua qualidade, eliminando-se assim, dificuldades na manutenção e das tendências de manejo e plantio levados a efeito da população. 


\title{
QUALI-QUANTITATIVE INVENTORY OF THE STREET ARBORIZATION OF ÁGUAS DE SÃO PEDRO RESORT - SP - BRAZIL
}

\author{
Author: SILVANA BORTOLETO \\ Adviser: Prof. Dr. ROBERVAL DE CÁSSIA SALVADOR RIBEIRO
}

\section{SUMMARY}

Street arborization plays an important role on keeping the physical and environmental balance in urban areas thus, improving the life quality. Lack of planning on its implantation and maintenance can jeopardize its efficiency. The knowledge of the street tree and shrub assets as well as their overall conditions can support the correct decisions on high quality arborization. The present work describes a quali-quantitative survey on street arborization of Águas de São Pedro Resort, in São Paulo State, Brazil. Census is the type of inventory used in this research; therefore, all individuals planted on streets sidewalks have been assessed. A number of 3,654 individuals were analyzed, comprising 161 species, 126 genus and 54 families. A total of $61.33 \%$ species were found to be exotic whilst $38.67 \%$ were native. According to their growth habit, $70.85 \%$ were classified as trees, $19.90 \%$ shrubs, 6.05 palms and $3.20 \%$ conifers. The ShannonWiener diversity index was found to be 3.90. Only a discreet predominance of Caesalpinia peltophoroides (sibipiruna) was observed, which represented $13.36 \%$ of all street arborization of Águas de São Pedro. The average index of individuals per kilometer of street was 130 , which can be considered high, despite the growth habit not 
being considered in the calculations. There is a trend in planting shrubs instead of trees, especially in recent years, which should be reversed. This work contains recommendations on the management, new planting of trees and replacements, adaptation and management of newly planted individuals, adequate pruning and improvement of the planting of native trees over the shrubby species. There is also a need to implement a directive plan in order to improve the quality of the arborization. This plan should bring positive effects on reducing difficulties on management as well as controlling both the planting and management carried out by the local population. 


\section{INTRODUÇÃO}

O aprofundamento dos estudos relativos à arborização urbana tem sido cada vez mais valorizado, na medida em que estes contribuem para a manutenção do equilíbrio físico-ambiental das cidades.

Há importantes questões levantadas nesses estudos. Uma delas é o fato de a arborização caracterizar a paisagem de ruas, praças e parques, realçando, assim, o ambiente da cidade (Lombardo, 1990). Outra questão relevante é que os locais arborizados desencadeiam nos sentidos humanos efeitos psicológicos e físicos, que se traduzem em qualidade de vida (Lombardo 1990; Demétrio 1997; Rachid 1999; Silva, 2000; Paiva \& Gonçalves, 2002; Silva Filho, 2002; Meneguetti 2003).

Muitos desses efeitos foram perdidos ao longo do processo de afastamento do homem da natureza. Contudo, esse processo de perda pode ser compensado quando se alcança a recuperação desse ambiente natural perdido nas cidades, por meio de projetos de arborização (Santos, 1994).

Os projetos de arborização devem respeitar os valores culturais, ambientais e de memória da cidade. Dessa forma, devem considerar sua ação potencial de proporcionar conforto para as moradias, sombreamento, abrigo e alimento para a avifauna, bem como atentar para a diversidade biológica, a diminuição da poluição, as condições de permeabilidade do solo e a paisagem, contribuindo, assim, para a melhoria das condições urbanísticas (São Paulo, 2002).

Entretanto, muitas cidades brasileiras não possuem um planejamento adequado de arborização urbana, na medida em que muitos projetos baseiam-se em métodos

puramente empíricos, desprovidos de um conhecimento real do assunto. Como conseqüência dessa inadequação, a arborização empreendida mostra-se ineficaz, pois os 
benefícios - que esta poderia, potencialmente, proporcionar à população - não são observados.

Para o planejamento do mais acertado manejo, requer-se conhecimento do patrimônio arbóreo existente na cidade e da situação atual da arborização por meio de um inventário (Meneguetti, 2003).

As decisões de manejo devem ser tomadas com base nos dados inventariados da arborização, devendo-se integrar as considerações acerca dos recursos naturais e os fatores sociais (Silva, 2000).

A partir da premissa de que o planejamento de arborização é de essencial importância para alcançar êxito, o presente trabalho ocupa-se, em específico, do levantamento quali-quantitativo da arborização viária da Estância de Águas de São Pedro, buscando dar diretrizes que nortearão as tomadas de decisão na elaboração de um planejamento futuro. Objetiva-se, por meio deste, propor sugestões e indicações de manejo. 


\section{REVISÃO DE LITERATURA}

\subsection{Breve histórico da arborização urbana}

\subsubsection{A arborização urbana ocidental}

$\mathrm{Na}$ Europa, entre a segunda metade do século XV e o século XVIII, significativas intervenções transformaram as paisagens das suas principais cidades, caracterizando praças e jardins de uma época. Em 1578, na Antuérpia, uma ordem do conselho dessa cidade determinava o plantio de três linhas de árvores nos passeios e as fortificações da cidade, com largas vias de circulação, deveriam ser ornamentadas por árvores. O jardim e o parque público, criações marcantes na urbanização européia a partir do século XVI, não negam, em sua formulação, o envolvimento estético e mitológico com a natureza. O primeiro grande espaço aberto europeu e a mais impressionante e influente contribuição peninsular foi a Piazza Obliqua de São Pedro de Roma, obra de Lorenzo Bernini, realizada entre 1647 a 1651 (Segawa, 1996).

Deve-se às iniciativas pioneiras das cidades de Londres (squares) e Paris (boulevards), a introdução de árvores na malha urbana (Santos \& Teixeira, 2001). Em Paris, a arborização das avenidas tornou-se obrigatória segundo uma legislação e a colocação de árvores nos lados e/ou no centro das vias públicas deu nascimento aos famosos boulevards parisienses (Terra, 2000).

A partir do século XVII, toda cidade importante na Europa construiu seu passeio ajardinado, como nas cidades de Dublin na Irlanda, Amsterdã na Holanda e Hamburgo e Berlim na Alemanha. Construiu-se também alamedas arborizadas que ligavam as cidades a um parque de caça no campo, como em Viena na Áustria, São 
Petersburgo na Rússia e Nancy na França (Girouard ${ }^{1}$ citado por Segawa, 1996).

Durante a gestão do Barão Haussmann, Paris passou por profundas transformações urbanísticas. Seus novos parques e jardins públicos, arquitetados sob a égide de Alphand, possuíam ambientes cenograficamente inspirados em uma visão pastoril e romântica, típica do parque inglês dos séculos XVIII e XIX, adaptados à visão nacionalista francesa (Macedo \& Sakata, 2002).

A alameda tornou-se um dos importantes sítios urbanos ao longo de todo o século XIX (Segawa, 1996).

\subsubsection{A arborização urbana no Brasil}

No Brasil, não há uma longa tradição na elaboração de grandes jardins e foi somente a partir do século XVIII que nasceu a preocupação em criá-los (Terra, 2000). Nas cidades brasileiras, à época colonial, os jardins eram restritos às propriedades religiosas ou aos quintais das residências. Existiam, também, alguns hortos e jardins botânicos, que tinham como função específica possibilitar a pesquisa e a investigação da flora nativa (Robba \& Macedo, 2002).

Nos seus três primeiros séculos, o Brasil foi uma simples colônia portuguesa, não existindo uma urbanização de porte, e sim modestas aglomerações (Macedo, 1999). A par dessa incipiente urbanização, havia a luta inicial dos colonos, que concentravam os esforços para afastar a natureza dos limites da aldeia (Trindade, 1997). É importante lembrar que a própria cultura portuguesa não valorizava a arborização urbana.

No período da ocupação holandesa no Recife, entretanto, houve uma tentativa de reproduzir nessa cidade características próprias de cidades européias. Dessa forma, foram plantadas centelhas de palmeiras, laranjeiras e granadilhas ao redor do palácio do governador (Terra, 2000). Devido a essa iniciativa, Recife foi provavelmente o primeiro núcleo urbano a dispor de arborização de rua no continente americano e teve o primeiro

\footnotetext{
${ }^{1}$ GIROUARD, M. Cities and people: a social and architectural history. New Haven: Yale University
} Press, 1985. 
parque público construído no Brasil: o do Palácio de Friburgo, desaparecido após a retirada dos holandeses de Pernambuco. Nas demais cidades brasileiras, as ruas, os largos e os terreiros foram tratados de um modo muito singelo, quando muito são calçados, com ausência da vegetação (Macedo, 1999).

Em 1783, foi inaugurado no Rio de Janeiro o primeiro jardim estruturado nas proximidades do contexto urbano, o Passeio Público (Terra, 2000). Porém, a importação de um modelo europeu, diante das diferenças entre as sociedades brasileira e européia, levou à falência do logradouro (Robba \& Macedo, 2002).

Com a chegada da Família Real ao Rio de Janeiro em 1808, foram introduzidos na cidade vários costumes europeus (Trindade, 1997). A cidade passou pelas mais rápidas e urgentes transformações urbanas e, em 1822, tornou-se a capital de uma nova nação (Macedo \& Sakata, 2002).

Houve a criação do Real Horto, o marco inicial do serviço de arborização pública do Rio Janeiro, cujas finalidades eram a aclimatação e o cultivo de espécies exóticas. As primeiras mudas plantadas foram de jaqueiras, abacateiros, fruta-pão, cajámanga, dentre outras (Milano \& Dalcin, 2000).

Na segunda metade do século XIX, foram reproduzidos no Brasil hábitos parisienses e, como decorrência desses novos costumes, as vias de circulação ganharam dimensões mais generosas e arborização mais sistemática (Macedo, 1999). Porém, o que impulsionou definitivamente a arborização pública da cidade do Rio de Janeiro foi a chegada, em 1860, do arquiteto francês Auguste Marie Glaziou. Contratado por D. Pedro II para reformar o passeio público, ele foi responsável também pelos projetos da Quinta da Boa Vista e do Campo de Santana, nos quais utilizou inúmeras espécies da flora nativa. Em 1869 e 1874, foram estabelecidas regras para plantios em ruas, como o espaçamento de 7 metros entre árvores, a altura mínima de 3 metros para as mudas, a obrigatoriedade do uso de protetores e a melhoria do substrato de plantio (Milano \& Dalcin, 2000).

$\mathrm{Na}$ virada do século XX, as ruas dos novos bairros eram largas e arborizadas. Em 1905, houve a abertura da Avenida Central, no Rio de Janeiro, a construção do primeiro boulevard em área central urbana brasileira e da Avenida Beira-Mar, em 1904. 
No núcleo antigo da cidade de São Paulo, ocorre o alargamento de ruas. Na capital amazonense, observa-se a construção de ruas e avenidas arborizadas e da Avenida Eduardo Ribeiro, que além de larga, iluminada, arborizada e com calçadas de grandes dimensões, apresentava um boulevard. Em 1897, Belo Horizonte foi desenhada com traçado de grelha, cortada por eixos arborizados que, na realidade, formavam grandes boulevards (Macedo, 1999).

Nas décadas de 30 e 40 do século passado e no período posterior à Segunda Guerra Mundial, o Brasil caracterizou-se por um aumento da classe média na população (Macedo \& Sakata, 2002). A partir de 1940, começaram a aparecer os primeiros sinais de mudança na concepção de espaços livres da cidade brasileira. Burle Marx é um dos exemplos dessa mudança, na medida em que ele rompeu com as escolas tradicionais e o academicismo. Dentre as inovações, deve-se ressaltar que os projetos passaram a ter atividades de lazer ativo (Robba \& Macedo, 2002). A vegetação nativa foi supervalorizada e adotou-se uma forte postura nacionalista, com caráter de ruptura e de abandono em relação a qualquer referência do passado imediato (Macedo, 1999).

A partir da segunda década do século $\mathrm{XX}$, os núcleos urbanos brasileiros começaram a se expandir muito rapidamente e boulevards e parkways foram abertos (Robba \& Macedo, 2002).

Com o surgimento da luz elétrica, a expansão dos serviços de abastecimento de água, de coleta de esgoto e de telecomunicações, um complexo sistema de cabos, galerias e dutos tomaram conta do ar e do subsolo. Como decorrência dessas inovações, pode-se apontar o fato de que a rede aérea passou a interferir no plano de arborização da cidade, com as áreas verdes ficando cada vez mais restritas à arborização de ruas, praças, parques e maciços florestais. É possível observar também que houve perda nos espaços de jardins privados e aumento da impermeabilização do solo (Milano \& Dalcin, 2000).

Durante o século XX, o crescimento urbano brasileiro foi intenso e, nos anos 90, a maioria da população habitava núcleos urbanos (Macedo \& Sakata, 2002). No final desse século, observam-se grandes regiões metropolitanas abrigando enormes contingentes de pessoas e enfrentando uma série de problemas urbanísticos. $\mathrm{O}$ aumento do tráfego de veículos e de pessoas, a escalada da violência, a degradação progressiva do 
ecossistema urbano e da qualidade de vida na cidade, além da dificuldade de gerenciamento desses fatores, são alguns dos problemas que se abateram sobre nossas maiores cidades (Robba \& Macedo, 2002).

Foi no século XX que a fisionomia das cidades foi alterada: houve profundas mudanças em nome da modernidade e surgiram grandes projetos e projetistas. Foi um século marcado por perdas de patrimônios arquitetônico e vegetal e pela ruptura da relação homem-natureza. Essa ruptura impôs a presença da árvore, porém a forma como foram distribuídos os espaços urbanos não proporcionou as condições adequadas ao desenvolvimento da vegetação (Santos \& Teixeira, 2001).

Foi nesse período que o Brasil sofreu seu mais agressivo e descontrolado processo de urbanização e industrialização. Os meados dos anos 80 foram a época em que menos se produziu conhecimento e informação técnica em arborização no país (Milano \& Dalcin, 2000).

No final do milênio, surgiram propostas de revitalização de bairros antigos para solucionar problemas de degradação do tecido urbano (Robba \& Macedo, 2002).

A rua, apesar de perder em parte sua flexibilidade funcional com o aumento do volume de tráfego, mantém-se como o principal espaço livre urbano. Nesse final de século, a rua continua sendo - principalmente nos bairros mais populares - o espaço de conversa, comércio, passeio e brincadeira, já que os espaços especialmente dedicados ao lazer público são escassos (Macedo, 1999).

\subsubsection{A Estância de Águas de São Pedro e sua arborização}

Foi na década de 20 do século passado que inicialmente se despertou o interesse pela área atualmente ocupada pela Estância, devido à procura de petróleo pelo Governo do Estado de São Paulo e pela iniciativa privada. Porém, o "ouro negro" não foi encontrado e, em vez disso, foram descobertas suas águas medicinais, ricas em minerais e em grandes quantidades (Águas de São Pedro, 2004). 
A região era formada por antigas fazendas produtoras de café, que foram abandonadas em conseqüência da crise de 1929 (Águas de São Pedro, 2004). Não havia matas a serem derrubadas e as culturas praticamente se extinguiram, em função da própria crise e do depauperamento do solo. Como indicativo dessa situação de abandono e depauperamento, havia apenas sobrado o capim "barba de bode" (Andrade ${ }^{2}$ ).

Em 1934, um grupo de pessoas comprou uma área de quatro alqueires de terra e construiu um balneário de alvenaria. Foi também nesse ano que Octavio Moura Andrade resolveu implantar a Estância, a qual provisoriamente denominou "Caldas de São Pedro" (Águas de São Pedro, 2004).

De posse dos resultados das primeiras análises da qualidade das águas, Octavio Moura Andrade e seu irmão adquiriram 650 alqueires de terra com o intuito de se construir uma nova cidade, então denominada Estância de Águas de São Pedro (Andrade ${ }^{3}$ ).

O projeto de urbanização foi confiado ao Engenheiro Jorge de Macedo Vieira, que planejou uma cidade que fosse um exemplo de “cidade-jardim", com amplos parques, áreas verdes, ruas largas, suaves e sem grandes aclives. No projeto, destacavam-se as seguintes características: a maioria das quadras como residenciais, uma área industrial e áreas destinadas a parques e florestas (Águas de São Pedro, 2004).

No Parque Florestal, ao redor do Grande Hotel, atualmente denominado "Parque Dr. Octavio Moura Andrade", e em outras áreas da Estância, foram plantados 1.200.000 pés de eucalipto, além de flamboyants, acácias, grevilhas, tipuana, ipês, pausbrasil, jacarandás, palmeiras, entre outras árvores $\left(\right.$ Andrade $\left.^{3}\right)$. A preferência pelos eucaliptos deu-se em virtude de seu rápido crescimento e da necessidade de sombra e ar

${ }^{2}$ ANDRADE, A.F.M. “A urbanização de Águas de São Pedro. Águas de São Pedro, 1987. (material fornecido pela Prefeitura Municipal de Águas de São Pedro).

3 ANDRADE, A.F.de M. Escorço histórico de “Águas de São Pedro”. Águas de São Pedro, 1975. (material fornecido pela Prefeitura Municipal de Águas de São Pedro). 
puro. Na época estavam disseminadas as propriedades terapêuticas dos eucaliptos na cultura popular.

O plano paisagístico do referido Parque foi elaborado por Júlio Bosshard, juntamente com o engenheiro de urbanização (Andrade ${ }^{2}$ ).

As características encontradas por ocasião desse plantio eram as de um vale devastado, resultantes do mau uso do solo, de textura arenosa, de baixa mineralização e de piçarra. Como esses fatores dificultavam o desenvolvimento das plantas, foram necessários, para o plantio de cada árvore, o feitio de covas de até 3 metros de profundidade (Fundação Roberto Marinho ${ }^{4}$ ) e a troca do solo por uma terra mais fértil, vinda de outra região (Andrade $\left.{ }^{3}\right)$.

O loteamento ficou com ruas largas - as principais com $14 \mathrm{~m}$ e as secundárias com 12; lotes de $600 \mathrm{~m}^{2}$, áreas verdes, praças e parques, além de cada esquina possuir uma área verde. Vinte anos depois, na década de 1960, mais dois loteamentos foram projetados, porém com lotes de $310 \mathrm{~m}^{2}$ (Andrade ${ }^{2}$ ).

O projeto de infra-estrutura sanitária foi confiado ao Escritório Técnico Saturnino de Brito, que planejou o saneamento de lagoas e brejos de águas paradas, a rede de esgoto, a implantação do canal central e o serviço de abastecimento de água potável (Águas de São Pedro, 2004).

Depois da criação da Estância de Águas de São Pedro em 1940 e da desapropriação do Grande Hotel e do Parque em 1951, esse planejamento passou a sofrer agressões ou modificações: lotes grandes foram divididos em dois; o Governo do Estado dividiu o Parque Dr. Octavio Moura Andrade para doar parte ao Serviço Nacional de Aprendizagem Comercial (SENAC) e o restante à Prefeitura Municipal; parte de ruas e praças de retorno foi alienada pela Prefeitura aos terrenos limítrofes; construções comerciais invadiram áreas residenciais; a represa, fonte de água potável da cidade, foi praticamente assoreada e pontos de obstrução dificultaram o escoamento da rede de esgoto da cidade $\left(\right.$ Andrade $^{2}$ ). Como a arborização de ruas não recebeu um

4 FUNDAÇÃO ROBERTO MARINHO. Programa Globo Ecologia, nº 510: “Águas de São Pedro”, Raiz Savaget Comunicação, Rio de Janeiro, 2000. 
planejamento de manejo, esta ficou a cargo dos moradores locais, turistas e companhias elétricas.

\subsection{Aspectos quali-quantitativos da arborização urbana}

\subsubsection{Urbanização e impacto ambiental}

No Brasil, a partir da metade do século XX, o modelo de desenvolvimento gerou um processo de urbanização intenso e acelerado, o que trouxe conseqüências na demanda de serviços de infraestrutura. Assim, instaurou-se um conflito pela conquista desses espaços, entre árvores, veículos, obras de construção e equipamentos públicos necessários (Meneguetti, 2003).

Essa transformação da paisagem em um cenário urbano modifica os elementos naturais, como solo, temperatura, umidade, nebulosidade, mecanismos do vento, pluviosidade, flora e fauna. Esses elementos naturais são responsáveis, no geral, pelas condições de conforto ambiental e de qualidade do ar (Lombardo, 1990; Santos \& Teixeira, 2001).

As cidades têm, como resultantes desse processo de urbanização, grandes superfícies com impermeabilização na quase totalidade dos seus solos e elevado índice de reflexão (Kirchner et al., 1990).

A grande concentração de pavimentos e construções nas cidades favorece a absorção de radiação solar diurna e a reflexão noturna. O fenômeno das "ilhas de calor" provoca um diferencial térmico bastante significativo se comparado a locais vegetados (Lima, 1993).

Essa alteração no balanço de energia reflete a interferência humana na dinâmica dos sistemas ambientais, referenciando o máximo da atuação do homem nas cidades sobre a organização da superfície terrestre. A concentração de construções e indústrias, o adensamento populacional, o asfaltamento e a poluição criam condições para alterar o comportamento da baixa troposfera nas cidades. Estudos mostram que as maiores diferenças de temperatura entre campo e cidade registraram $5^{\circ} \mathrm{C}$. Na cidade de São 
Paulo, entretanto, ultrapassam-se essas medidas, que alcançam um gradiente de temperatura horizontal superior a $10^{\circ} \mathrm{C}$ entre área rural e centro, pois em locais onde a concentração de poluentes tem valores mais altos, ocorrem as mais elevadas temperaturas. As alterações climáticas mais significativas no ambiente urbano são a temperatura e a concentração de poluentes, as quais tornam-se possíveis de serem utilizadas como indicadores de degradação ambiental. É no centro das cidades, em locais pouco vegetados, que as temperaturas chegam a valores máximos, enquanto os valores mínimos são obtidos em áreas verdes e reservatórios d'água. Um dado importante é o fato de que com esse aumento de temperatura das áreas urbanas, ocorre diminuição da umidade relativa (Lombardo, 1990).

Os graus de intervenção aliados às características geográficas e sócio-políticas representam o diferencial das cidades e atestam seu grau de deterioração. Nesse contexto, onde os fatores negativos se somam, o papel da arborização das vias públicas assume importância como um dos fatores de qualidade de vida (Santos \& Teixeira, 2001).

Os benefícios ambientais gerados pela arborização de ruas e pela arborização urbana são tão mais necessários à saúde ambiental do ecossistema urbano quanto maior se apresenta o nível de urbanização (Meneguetti, 2003).

\subsubsection{Arborização urbana e o conforto ambiental}

O clima em geral é inalterável com o desenho da paisagem, mas em relação ao microclima, este pode ser alterado (Paiva \& Gonçalves, 2002). Dessa forma, a vegetação assume benefícios comprovados, que vão desde a melhoria microclimática - por meio da diminuição da reflexão das radiações, do aumento da umidade atmosférica e da conseqüente amenização das temperaturas -, passam pelos benefícios econômicos resultantes da valorização de propriedades, até o controle das poluições atmosférica, acústica e visual, os benefícios sociais e a ação benéfica à saúde humana física e mental 
(Kirchner et al., 1990). Outro dado é que a vegetação interfere também na direção e na velocidade do vento (Lombardo, 1990).

Dados apontam que uma árvore, isoladamente, pode transpirar em média até 400 litros de água por dia, o que equivale ao funcionamento de cinco condicionadores de ar com capacidade de 2500 quilocalorias cada, acionados 20 horas por dia (Eletropaulo, 1995). Sabe-se que os conjuntos arbóreos são responsáveis pela redução da temperatura do ar e que esses valores são variáveis de acordo com o grau de fechamento das copas, do número de espécies, de indivíduos e da estação do ano (Santos \& Teixeira, 2001).

Heisler (1974) ressalta que além das áreas vegetadas, a própria arborização de ruas pode abrandar o processo de aquecimento e atenuar as "ilhas de calor" e que essa atenuação explica-se pela capacidade que as árvores têm de interceptação da radiação solar: as árvores que possuem copa rala podem interceptar em até $80 \%$ a radiação solar, enquanto que as de copa densa, em até $98 \%$. Isso mostra a importância da vegetação contra a insolação prolongada e o desconforto térmico.

Em um estudo direcionado para a avaliação do efeito potencial das sombras das árvores sobre a economia de energia elétrica demandada pelo aparelho de ar condicionado, observou-se que essa economia foi maior nos locais de climas mais quentes e em locais de construções agrupadas. Três árvores (duas no oeste e uma no lado leste da construção) reduziram a energia anual usada para o resfriamento de 10 a $50 \%$. A exceção, nesses dados, ocorreu em climas com pouca demanda de ar condicionado. A recomendação para maximizar essa economia, no caso do hemisfério norte, está relacionada às posições da árvore e da construção: uma única árvore deveria ser localizada no oeste ou sudoeste, no exterior da janela, providenciando assim o máximo de sombra e economia (Simpson \& McPherson, 1996).

Folhas, galhos e troncos têm a capacidade de remover material sólido ou líquido particulado do ar. Isso ocorre quando a precipitação do ambiente é intensa, lavando esse material e transportando-o para cursos d'água e solo. O intenso tráfego de veículos, a queima de combustíveis fósseis, a madeira, o carvão e as atividades de construção são fontes que geram esse material particulado. O efeito obstáculo produzido 
pela planta reduz a chance do material depositado ser novamente carregado pelo vento (Firkowski, 1990).

Ruas bem arborizadas podem reter até $70 \%$ da poeira em suspensão e, mesmo no inverno, quando se apresentam desfolhadas, as caducifólias retêm até $60 \%$ de sua capacidade total. A remoção de gases tóxicos existentes na atmosfera pelas plantas ocorre quando esses gases se encontram retidos no material particulado, sendo filtrados conjuntamente. Se esses gases forem tóxicos, mas se apresentarem em doses subletais, eles permanecerão inócuos; já em doses letais, as plantas poderão ter seu desenvolvimento comprometido (Santos \& Teixeira, 2001).

Outro importante benefício da arborização é o efeito da redução dos níveis de ruídos (poluição sonora), que se dá por absorção, refratação e refleteção das ondas sonoras. A eficiência dessa redução depende de vários fatores, como: o nível do ruído, a topografia, as características das espécies, a forma e o arranjo das plantas, a superfície foliar, a freqüência do som, a posição da vegetação e a estação do ano (Santos \& Teixeira, 2001).

A arborização também atua no sistema hidrológico. Quando a água das chuvas cai na cidade, ela se dissipa de várias formas: parte retorna ao ar pela evapotranspiração, perpetuando o ciclo da água e fazendo chover; parte se infiltra no solo, indo abastecer os lençóis de águas; parte se infiltra superficialmente, umedecendo o solo; parte escorre por sobre a superfície do solo e, se intensa, causa erosões, deslizamentos, enchentes e empobrecimento do solo (Paiva \& Gonçalves, 2002).

Os solos da cidade, impermeabilizados por cimento e asfalto, têm escoamento superficial e intenso, pois quase toda a água escorre pelas ruas. Se o sistema de drenagem da cidade não funciona adequadamente, ocorrem inundações. Uma cidade bem arborizada pode apresentar um melhor ciclo hidrológico, fato que pode ser percebido quando são comparadas as condições urbanas e rurais: nota-se que a precipitação é de 5 a 10\% maior no meio urbano, valores também encontrados quando se compara a nebulosidade dos dois meios. Em relação à umidade relativa, observa-se uma diminuição no meio urbano, que chega a ser $2 \%$ menor no inverno e $8 \%$ menor no verão (Paiva \& Gonçalves, 2002). 
As florestas desempenham um papel importante no combate à erosão. As primeiras chuvas, ao caírem sobre um bosque, deixam no solo em média 90 a 95\% de suas águas, contra apenas $10 \%$ na terra nua. Nesta, o restante das águas segue cavando sulcos e determinando as cheias (Soares, 1998).

\subsubsection{Arborização viária}

O efeito da urbanização acelerada tem provocado grandes modificações sobre a paisagem. A ação antrópica causa danos drásticos, principalmente aos fragmentos remanescentes da vegetação. O homem, para adaptar-se ao ambiente, o transforma, modificando sua ecologia (Alvarez et al., 2003).

O planejamento e o projeto de arborização urbana pública e privada estão inseridos na ecologia urbana, num ecossistema (Busarello, 1990).

A arborização de ruas é um dos elementos vegetados dos ecossistemas urbanos capazes de integrar espaços livres, áreas verdes e remanescentes florestais, conectando todos esses ambientes de forma a colaborar com a diversidade da flora e da fauna (Rachid, 1999; Paiva \& Gonçalves, 2002; Meneguetti, 2003).

A fragmentação das florestas ocorre com freqüência nas diversas regiões do país, transformando grandes extensões de habitats em numerosas porções de vegetação expressivamente menores e isoladas umas das outras. A diversidade é invariavelmente reduzida pelas modificações causadas nesse processo de fragmentação (São Paulo, 2000).

As árvores do meio urbano estão constantemente interagindo beneficamente com outras espécies, em especial líquens e pássaros. Os líquens são indicadores de qualidade do ar e os pássaros, indicadores de vida em comunidade. $\mathrm{O}$ fato de todas essas populações interagirem propicia maior sustentabilidade à comunidade. Uma espécie de pássaro pode estar, por exemplo, controlando o aumento indesejável de insetos predadores e o mesmo pode acontecer com os líquens em relação a microorganismos, ou seja, quanto maior a diversidade ecológica, melhor a segurança do ecossistema urbano 
(Silva Filho, 2002). O uso da vegetação, ao longo da malha urbana, constitui-se na forma de preservação do equilíbrio biológico (Santos \& Teixeira, 2001).

A maioria das plantas arbóreas cultivadas em ruas, avenidas, praças e jardins do Brasil é formada de espécies oriundas de outros países (espécies exóticas), apesar de a nossa flora contar com centenas de espécies de grande beleza e qualidade paisagística. Além dessas qualidades estéticas, a flora brasileira proporciona alimento à avifauna e, se fossem mais utilizadas na arborização urbanística, se possibilitaria inclusive resgatar muitas espécies do limiar da extinção. Portanto, as espécies exóticas não são as substitutas ideais para a vegetação nativa, quando se levam em conta todas as funções que desempenham no ecossistema (Lorenzi, 2002b).

\subsubsection{Características de espécies adequadas à arborização viária}

Várias referências ressaltam as características "ideais" de mudas de árvores e arbustos para a arborização viária, tais como Santos \& Teixeira (2001), Águas de São Pedro (2001) e Companhia Energética de Minas Gerais (2001). Observa-se que há uma convergência dessas características, o que culmina em conceitos muito similares:

- sistema radicular pivotante;

- fuste de aproximadamente 1,80m de altura, requerendo a escolha de espécies com essa característica ou de mudas com intervenções praticadas no viveiro;

- tamanho e textura de folhas que não promovam entupimentos;

- sem presença de espinhos e princípios alérgicos;

- não tóxicas;

- com maior resistência fitossanitárias, quando cultivadas no espaço urbano;

- árvores de crescimento rápido são mais indicadas;

- possibilidade do uso de frutíferas, evitando-se as espécies de fruto grande;

- uso criterioso de arbustos;

- escolha de espécies de distintos portes e formatos, respeitando a respectiva arquitetura, que podem ser classificadas em seis tipos: 
-guarda-chuva: de grande porte e copas altas, requer espaço amplo e ausência de fiação aérea;

-globoso: de porte pequeno a médio, tronco curto, copa baixa e com densa folhagem;

-chorona: com ramos pendentes, dificultam o trânsito nas calçadas;

-piramidal: de porte médio a grande, geralmente conflita com a fiação aérea e o rebaixamento da copa pode comprometer sua estrutura; -colunar: com porte vertical, qualquer intervenção descaracteriza os exemplares;

-irregular: sua falta de definição na copa permite compatibilizála à fiação.

No entanto, observa-se, que o ítem "escolha de espécies ideais de distintos portes e formatos" está sendo considerado sob o ponto de vista das concessionárias de serviços públicos e nem sempre condizem com as desejadas funções paisagísticas e ambientais necessárias à arborização de vias públicas. Alguns autores se referem à valorização do elemento arbóreo e a adequação das outras utilidades públicas (fiação aérea, iluminação) como economicamente vantajosas (Cerezo \& Martins, 1994; Farhat \& Maróstica, 1994; Kuguimiya, 1994; Velasco, 2003).

\subsubsection{Situação das árvores em vias públicas}

Em razão de o espaço das vias públicas ser exíguo, não é fácil harmonizar a presença de equipamentos urbanos (instalações hidráulicas, redes elétricas, telefônicas ou sanitárias) com a implantação do verde. Toda iniciativa desse tipo complica-se quando se considera a largura e a orientação das ruas, o porte das edifícações, a topografia do terreno, a natureza do solo, o clima e as exigências funcionais do zoneamento urbano (Soares, 1998). 
Nesse espaço, o plantio de árvores reveste-se de sérias implicações e requer, assim, atenção especial. Na malha urbana, ocorrem problemas bem diversificados e realmente limitadores de uma perfeita arborização. Nas calçadas das ruas, muitos fatores concorrerão para que sua arborização não se desenvolva da forma ideal, pois estará contida, limitada por diversas circunstâncias. Devem ser considerados fatores naturais, fatores decorrentes da influência antrópica (culturais) e fatores inerentes ao espaço urbano (largura de ruas, calçadas, impermeabilização excessiva, equipamentos urbanos, entre outros) (Grenha, 1997).

O ambiente da arborização de ruas é bastante restritivo para o crescimento das árvores. Fatores como compactação e contaminação do solo, podas drásticas, diversidade pequena de espécies, depredação, estresse hídrico, temperaturas extremas e iluminação noturna, entre outros, concorrem para uma saúde comparativamente menor dessas árvores (Meneguetti, 2003).

A introdução da arborização viária é realizada, geralmente, ao término das obras civis. É comum a utilização de entulhos para o assentamento do piso nas calçadas, além de os terrenos em obra apresentarem-se sujeitos ao tráfego de caminhões pesados, compactando o solo. Tais intercorrências implicam em maior resistência à penetração das raízes, menor infiltração de água e menor circulação de ar e água. No preparo das covas para plantio, são comuns a falta de adubação química ou orgânica ou ainda a troca por terra de boa qualidade (Santos \& Teixeira, 2001).

As árvores são submetidas a fatores de estresse, como podas pesadas, ação de vândalos, ausência de área livre de canteiro e grande circulação de veículos, entre outros (Silva Filho, 2002). Os poluentes do ar alteram os processos físicos e químicos das plantas ou produzem efeitos secundários, como a redução de troca gasosa devido à camada de pó sobre as folhas, os danos na membrana celular, a interferência no mecanismo de abertura e fechamento dos estômatos, a corrosão da cutícula das folhas e acículas, a diminuição da vitalidade e a maior suscetibilidade a pragas e doenças (Santos $\&$ Teixeira, 2001).

A perda média das mudas após o plantio nas ruas, por morte natural, é de aproximadamente $25 \%$ no primeiro ano de plantio e $15 \%$ no segundo ano. Já as mortes 
por depredação são de aproximadamente $20 \%$ no primeiro ano, $10 \%$ no segundo ano e $5 \%$ no terceiro ano. As mudas, em geral, conquistam autonomia depois do terceiro ano após plantio (Porto Alegre, 2002).

Nas vias públicas de bairros periféricos da cidade de Betim-MG, verificou-se perda de aproximadamente $80 \%$ dos indivíduos plantados. O porte baixo das mudas, o plantio sem grade de proteção, o alto índice de vandalismo e a deficiência da fiscalização foram as prováveis causas dos danos sofridos pela arborização (Alves \& Souza, 2003).

$\mathrm{Na}$ comparação das curvas de sobrevivência - nas quais interagem taxa de mortalidade, taxa de natalidade e idade da população - de árvores e humanos, notou-se que há alta mortalidade das árvores no estágio inicial de vida e que relativamente poucos indivíduos chegam a alcançar a idade adulta, ao contrário do que ocorre com humanos (Forman \& Godron, 1986).

As situações de conflito entre espaço vegetal e espaço físico disponível são diversas e se traduzem em exemplares mutilados, propensos a problemas sanitários (Santos \& Teixeira, 2001).

Monico (2001) concluiu em sua pesquisa que a arborização viária é comprometida pela inexistência de uma política pública favorável e definida para a questão da arborização urbana e que as mudanças de gestão política influenciam negativamente o quadro da arborização. As árvores de grande porte estão sendo sistematicamente substituídas por espécies de pequeno e de médio porte, possuidoras de menor efeito ambiental. Em inventário realizado na Estância Turística de Campos de Jordão, Andrade (2002) observou poucos plantios recentes em suas ruas e avenidas, o que indica falta de investimentos recentes.

Atualmente, as árvores das ruas e avenidas continuam sendo danificadas, mutiladas, ou mesmo eliminadas, quando se trata de reformas urbanas, como alargamento de vias, conserto de encanamentos, manutenção da rede elétrica, construção e reforma de edificações residenciais, comerciais e mesmo institucionais (Andrade, 2002). 


\subsubsection{Elementos urbanos e a poda na arborização viária}

O sistema viário ocupa, em geral, acima de $20 \%$ dos espaços urbanos e é fundamentalmente formado por ruas e avenidas, nas quais as árvores desempenham especial papel como elemento do desenho urbano, na medida em que contribuem para a melhoria estética da paisagem da cidade com suas formas, cores e texturas (Milano \& Dalcin, 2000). Contudo, a falta de planejamento e de conhecimento técnico gera indivíduos arbóreos mutilados, com sua arquitetura descaracterizada. Devido a podas mal realizadas, entre outras causas, observam-se indivíduos em início ou final de declínio, causando poluição visual e descaracterizando alguns aspectos da arborização viária.

Os objetivos e a real necessidade da prática da poda de árvores devem ser avaliados. A arquitetura do vegetal, sua fase de desenvolvimento e suas características devem ser observadas e mostra-se essencial haver pleno conhecimento por parte de quem executa a poda (Barcelos, 1997).

Dados da Eletropaulo (1995) mostram que 27,45\% das árvores morrem após serem podadas nas cidades do Estado de São Paulo, o que indica ser essa uma prática realizada sob aspectos técnicos e biológicos distantes do recomendável.

Estudos mostram que árvores de pau-brasil e sibipiruna com ataque de fungos apodrecedores, cupins xilófagos e brocas-de-madeira apresentavam como causas desses problemas os tratos de manejo e, principalmente, as podas realizadas inadequadamente. O manejo adequado das árvores torna-se essencial para a prevenção desses problemas (Amaral et al., 2003).

Comparações de prognósticos de árvores de Modesto e Santa Mônica (EUA) sugerem que práticas culturais, especialmente podas, têm um significante impacto no tamanho das árvores e na área foliar, potencialmente maior do que características de clima e solo (Peper et al., 2001).

As árvores urbanas, geralmente, não devem ser podadas. Recomendam-se apenas a poda de formação - para que a muda atinja um fuste de mais ou menos dois 
metros de altura - e o seu plantio correto, para não haver mutilação. Entretanto, a poda se faz necessária em caso de galhos secos, doentes ou mal colocados (Soares, 1998).

Ainda é comum o uso de podas pesadas, como o caso observado por Andrade (2002): "as atividades de manejo das árvores na cidade de Campos do Jordão, no ano de 2001, consistiram de podas de levantamento de copa e podas drásticas para todos os indivíduos localizados embaixo de fiação. Essa prática, além de alterar a arquitetura da copa e a fisiologia dos indivíduos, teve custos onerosos para a Prefeitura".

As podas severas devem ser evitadas, pois causam danos, como: a) apodrecimento da madeira; b) entrada de insetos e doenças; c) secamento da casca e do câmbio, expostos à insolação; d) enfraquecimento do sistema radicial; e) prejuízos estéticos à árvore. A poda provoca um desequilíbrio entre as folhas e as raízes, causando uma reação compensatória no vegetal, em intensidade proporcional, por meio da queda de dormência das gemas epicórmicas ou dos brotos ladrões, os quais possuem uma ligação deficiente com sua base e um crescimento extremamente rápido. Como conseqüência, ocorre o desrespeito ao modelo arquitetônico da espécie (Milano \& Dalcin, 2000). As podas praticadas pela população são culturalmente determinadas e apenas a prestação de serviços com qualidade e por técnicos especializados evitará a continuidade das agressões praticadas nas arborizações (Santos \& Teixeira, 2001).

Uma outra maneira de contornar o problema da competição pelo espaço é a escolha de árvores de pequeno porte para locais sob fiação. Esse artifício pode funcionar bem para as cidades de clima ameno, mas para as cidades de clima quente, não responde aos requisitos ambientais (Paiva \& Gonçalves, 2002).

Outro problema é o sistema de iluminação pública que às vezes se encontra sobre as copas das árvores, pois ao ter reduzido ou mesmo anulado seu objetivo de iluminar as vias públicas, gera problemas de insegurança à população. Esse impasse é comumente solucionado com poda pesada ou substituição por outras árvores de menor porte. Devem ser buscadas, para tais situações, soluções alternativas, como a encontrada pela cidade paranaense de Maringá, que adotou um novo sistema de iluminação pública, com luminárias mais simples, instaladas em altura mais baixa (Milano \& Dalcin, 2000). 
Os padrões das redes elétricas também podem - e devem - mudar, embora por muito tempo os técnicos das companhias elétricas as tenham considerado não reformuláveis. Algum pioneirismo e boa vontade de algumas companhias estão levando esse mito ao fim, como pode se notar, por exemplo, no uso de redes compactas em Maringá, posteriormente em Curitiba e, atualmente, em vários outros lugares, as quais compatibilizam árvores e redes (Milano \& Dalcin, 2000). Velasco (2003) afirma que há viabilidade na utilização de redes compactas de distribuição de energia elétrica em lugar de utilizar-se a rede convencional.

Podem ser apontadas importantes vantagens com o uso de redes subterrâneas, como: a) satisfatório estado geral das árvores; b) razoável porcentagem de árvores sem presença de poda; c) ausência de necessidade de podas drásticas; d) redução em um terço dos custos de manutenção; e) altíssima confiabilidade do sistema. Dessa forma, pode-se afirmar que embora demande alto investimento inicial, da ordem de 10 vezes maior em relação ao custo da rede convencional, o uso de redes subterrâneas é vantajoso (Velasco 2003).

\subsubsection{A arborização em municípios turísticos}

$\mathrm{O}$ atual interesse por temas relativos ao ambiente, independente das causas que o informam e das práticas sociais dele decorrentes, permite a interpretação de seus indícios como um desejo contemporâneo de retorno à natureza. Desejo que vem se traduzindo em algumas buscas como, por exemplo, a obsessão pela proteção da natureza e a valorização dos saberes de comunidades tradicionais, ou seja, a tentativa de reencontrar a natureza por meio do turismo, especialmente em sua variação ecológica ou ambiental (Serrano, 1999).

Os recursos cênicos, além das possíveis belezas naturais, incluem todas as formas de uso da terra, produção de águas minerais, represas, formações geológicas regionais, hábitos de espécies vegetais e animais, incluindo unidades de conservação (Mendez, 1997). 
A atividade de turismo necessita não apenas de pessoal qualificado (recursos humanos), como também de conhecimentos técnicos e científicos (recursos naturais) para garantir os atrativos naturais que justifiquem a constante visita. As atividades que se realizam no meio ambiente, fora das áreas intensamente urbanizadas, podem ser caminhadas, festivais, esportes na natureza, visitas à fauna e flora, gastronomia regional, hotéis fazenda (Negri Neto, 2003).

Nas cidades mais importantes do mundo, a preservação de seus bens ambientais e culturais, contribui para o sentimento positivo de identidade, despertando admiração e respeito por parte de quem as visita (Empresa brasileira de turismo, 2004).

Em pesquisa realizada na região de Campos de Jordão, concluiu-se que todos os projetos implantados visavam à especulação imobiliária, diversamente do que os turistas consultados desejavam, que seriam projetos ecológicos que visassem à integração do homem com a natureza (Pereira, 1999).

O município de Belém apresenta em seu espaço físico territorial urbano um patrimônio histórico e cultural muito rico, capaz de evidenciar a grandeza da cidade ao longo de sua trajetória evolutiva, fundamental para o processo de solidificação dos valores regional e local. Este fato ressalta uma das características da cidade que é a arborização do centro urbano de Belém que preserva em suas Praças, Bosques, Parques, ruas e avenidas, os túneis de folhagens criados pela natureza com os galhos das mangueiras, que evidencia a grande beleza dessa região: o verde (Teixeira \& Teixeira, 2004).

Maringá abriga em grande número um dos mais belos fenômenos paisagísticos: os túneis de árvores, em toda parte, formados por espécies que vão da acácia ao jacarandá, valorizados pela possibilidade turística e pela qualidade do ar. Cada rua ou praça tem a sua própria espécie, por exemplo, a Praça 7 de setembro, as acácias; a Praça Manoel Ribas, as quaresmeiras; a Avenida Brasil, os ipês roxo; há também sete parques na cidade, destacando-se o Ingá, estes possuem lago artificial, zoológico, jardim japonês, pista de cooper e áreas de lazer. Nomeando a cidade carinhosamente de "Cidade Verde" (Jornal Nipo, 2004). 
Dessa maneira, a Estância de Águas de São Pedro, tende a se beneficiar, investindo em um planejamento direcionado à valorização do verde, tanto viário como de praças, bosques e mesmo em áreas particulares.

\subsubsection{Adequação e planejamento da arborização urbana}

Em muitas situações, o planejamento urbano deixa de incluir a arborização como equipamento a ser devidamente planejado, o que permite, muitas vezes, que iniciativas particulares pontuais e desprovidas de conhecimento ocupem o espaço com plantios irregulares de espécies sem compatibilidade com o planejamento anterior. Como conseqüência, perde-se a eficácia da arborização em transmitir conforto físico e psíquico, acarretando infortúnios e transtornos. Esse tipo de procedimento é muito comum nas cidades brasileiras, o que causa, muitas vezes, sérios prejuízos (Silva Filho, 2002).

A fragilidade e a complexidade desse sistema a ser administrado requerem um planejamento cuidadoso, com os objetivos de otimizar as funções da arborização e de reduzir custos (Meneguetti, 2003).

Dessa forma, é fundamental que haja um planejamento adequado, com definição dos objetivos e das possíveis metas qualitativas e quantitativas, pois deve-se ter a clareza de que a inexistência de um plano a seguir e cumprir torna os processos de implantação e manejo da arborização puramente empíricos (Milano \& Dalcin, 2000).

A arborização urbana, para propiciar benefícios à população, exige um planejamento criterioso e um manejo adequado. Para tanto, torna-se necessário o conhecimento do patrimônio arbóreo, que pode ser obtido por meio de inventário, recurso que se constitui em uma ferramenta fundamental para a obtenção de informações precisas acerca da população arbórea (Silva et al., 2003).

A avaliação da cobertura de árvores na cidade pode ajudar no planejamento da vegetação urbana e na sua administração, na medida em que revela características da vegetação, determina a extensão e a distribuição da vegetação (Nowak et al., 1996). 
Os planos de arborização devem ser o resultado da apreciação de elementos físicos e ambientais, como: a) avaliação conjunta da largura dos passeios e canteiros; b) caracterização das vias; c) presença de fiação aérea; d) recuo das construções; tipologia das construções; f) largura da pista; g) características do solo; h) canalização subterrânea; i) orientação solar; j) atividades predominantes; 1) arborização implantada ou existente, para se elegerem as espécies mais adequadas. É certo que a simples presença de árvores ao longo das vias não qualifica a arborização, pois são comuns altas populações que incluem árvores quebradas, disformes, doentes e mortas (Santos \& Teixeira, 2001).

A arborização urbana pressupõe as atividades de planejamento, implantação e manutenção sob o poder público. Entretanto, normalmente, estas etapas da arborização são preteridas em função da implantação de redes elétricas, de redes de saneamento, de calçadas, de ruas, etc. O planejamento da arborização deve ser bem acompanhado para correção imediata de eventuais falhas e deve atender aos objetivos pré-determinados, além de ser continuamente avaliado e controlado (Kirchner et al., 1990).

A definição de metodologias para avaliação e diagnóstico da arborização depende de objetivos específicos. O processo de monitoramento, com a realização de avaliações específicas ou inventários, envolve etapas de avaliação de parâmetros, realização de inventário do patrimônio arbóreo e análise quali-quantitativo dos dados (Milano \& Dalcin, 2000). Obtém-se, dessa forma, um banco de dados que pode se tornar ferramenta de manejo e avaliação das árvores, pois possibilita a utilização do cadastro e a realização de comparações, análises e evolução do processo (Silva Filho, 2002).

\subsubsection{Métodos de amostragens de inventário}

Os objetivos da realização de um inventário arbóreo podem ser assim resumidos: a) conhecer o patrimônio arbóreo; b) definir uma política de administração a longo prazo; c) estabelecer previsões orçamentárias; d) preparar um programa de gerenciamento das árvores; e) identificar necessidades de manejo; f) definir prioridades 
nas intervenções; g) localizar áreas para o plantio; h) localizar árvores com necessidade de remoção; i) funcionar como instrumento de persuasão. Os parâmetros a serem avaliados agrupam-se em cinco categorias: localização das árvores, características destas árvores, características do meio, ações recomendadas e serviços executados (Motta, 2000).

Para a definição do inventário a ser utilizado, deve-se considerar a sua abrangência, uma vez que pode ser total, para as cidades de pequeno e médio portes, e parcial, para as de grande porte. No inventário total, os dados são coletados em toda a área do levantamento, diferentemente do inventário parcial, no qual opta-se pelo levantamento de certas áreas ou de ruas de maior interesse. Conclui-se, então, que os dados podem ser obtidos a partir de um levantamento completo, que leva em conta todos os indivíduos da população, ou por um sistema de amostragem, constituído por apenas parte da população (Motta, 2000). Os métodos de amostragens parciais constituem-se em um meio mais econômico de diagnosticar a arborização viária de uma cidade.

Há muitos estudos referentes aos tipos de amostragens utilizadas. Alguns desses estudos ocupam-se em apontar as amostragens mais indicadas e recomendadas para as várias situações que se apresentam. Embora as características locais tenham um papel preponderante na escolha do tipo de amostragem e possam mesmo apontar para a possibilidade de serem adotados sistemas de amostragem aleatórios, sistemáticos ou em conglomerados, têm sido mais comuns os procedimentos de amostragens aleatórios em função das características gerais da arborização das cidades. São utilizadas unidades amostrais retangulares e o número de árvores por quilômetro de calçada arborizada como variável principal. A amostragem aleatória, com unidades amostrais em linha, e amostragem em conglomerado, utilizando-se o quarteirão como bloco e as calçadas como unidades, demonstraram viabilidade de utilização com algumas vantagens em relação ao sistema anterior, embora requeiram mais testes experimentais (Milano, 1994).

Não obstante essas considerações, são os objetivos da avaliação, as características da cidade e, por conseqüência, dos dados a coletar, que definirão o sistema a ser adotado. Quando as características da cidade permitem, recomendam-se os 
processos de estratificação como forma de melhorar a precisão e reduzir os custos de realização de inventários (Milano, 1994).

Michi \& Couto (1996) compararam dois métodos de amostragem de árvores de rua da cidade de Piracicaba-SP e concluíram que ambos os métodos - amostragem por conglomerados e amostragem com probabilidade proporcional ao tamanho estratificado por bairros - podem ser utilizados nos inventários de arborização viária. Eles alertam, contudo, que o segundo método mostrou-se mais eficiente.

Rachid (1999) realizou um estudo comparativo de dois métodos de amostragem de árvores de rua da cidade de São Carlos-SP: a amostragem casual simples e a amostragem estratificada e, em ambos, utilizaram-se os quarteirões como unidades amostrais. $\mathrm{O}$ autor verificou que os dois métodos foram eficientes para realizar o levantamento arbóreo dessa cidade, porém observou melhor adequação no método de amostragem casual simples, pois o ganho em precisão proporcionado pelo método da estratificação não justifica o maior esforço que esse método demanda.

Meneghetti (2003), ao comparar a eficiência de dois métodos de amostragem de árvores de rua da cidade de Santos-SP - a amostragem sistemática simples e a amostragem estratificada por bairros -, verificou que ambos os métodos foram eficientes no levantamento de árvores de ruas para essa cidade, mas avaliou que a amostragem sistemática simples é a mais adequada, pois o ganho de precisão, quando se utiliza o método de estratificação por bairros, não é significante.

No Brasil, os métodos de amostragem de árvores de rua ainda necessitam de aperfeiçoamento sob o ponto de vista estatístico. Os métodos necessitam também de investigação científica mais ampla, para que se possa definir um único sistema que contemple diferentes condições e cidades (Couto, 1994) 


\section{MATERIAL E MÉTODOS}

\subsection{Local de estudo}

O estudo foi realizado na Estância de Águas de São Pedro, município do Estado de São Paulo. Sua área total perfaz $3,9 \mathrm{~km}^{2}$ e sua localização apresenta as seguintes referências: entre $22^{\circ} 35^{\prime} 58^{\prime \prime}$ Latitude Sul e $47^{\circ} 52^{\prime} 34^{\prime \prime}$ Longitude Oeste, fazendo divisa com o município de São Pedro em todo o seu perímetro (Águas de São Pedro, 2004).

A Estância apresenta altitude de $470 \mathrm{~m}$ e um relevo de depressão, com temperatura média anual de $27,2^{\circ} \mathrm{C}$ e índice pluviométrico de $500 \mathrm{~mm} / \mathrm{ano}$ (Águas de São Pedro, 2004).

Águas de São Pedro, como é também chamada, possui uma população urbana de 1.845 pessoas (Censo 2000-IBGE). A taxa de crescimento demográfico é de 4,06\% ao ano e a densidade demográfica é de 473,08 habitantes $/ \mathrm{km}^{2}$. A taxa de urbanização é de 100\%, não possuindo área rural (Águas de São Pedro, 2004).

A economia local é alicerçada no turismo, que é a atividade preponderante no município, muito procurado principalmente por suas águas medicinais. 


\subsection{Material de campo}

Seguem os instrumentos e os demais materiais utilizados, com as respectivas finalidades:

- hipsômetro Blume-Leiss: determinação da altura dos indivíduos;

- trena de 50 m e fita métrica de 1 m: verificação das demais medidas;

- caderno de planilhas para as anotações qualitativas;

- caderno de planilhas para as anotações quantitativas;

- jornal, papelão e barbante: confecção de exsicatas das espécies não identificadas in loco para posterior identificação pelo Departamento de Ciências Biológicas/ Área de Botânica/ ESALQ/ USP;

- $\quad$ aparelho Garmin GPS MAP-295: georreferenciamento de pontos da cidade.

\subsection{Levantamento de informações}

O método adotado para o inventário quali-quantitativo dos indivíduos das vias públicas da Estância de Águas de São Pedro foi do tipo censo, ou seja, foram inventariadas individualmente todos os indivíduos, na área total do município, excetuando-se as áreas verdes. Essa etapa, na qual foram medidos e anotados dados considerados importantes para a avaliação da arborização viária, norteou-se segundo a planilha desenvolvida por Silva Filho (2002). E apresenta a seguinte organização:

a) Anexo A: Localização e identificação; Biologia; Entorno e interferências e Definição de ações;

b) Anexo B: Dimensões.

Essas planilhas, ao direcionar e categorizar a atividade de observação, otimizou o desenvolvimento do trabalho de campo. A seguir, detalha-se o que foi realizado em cada um desses itens: 


\subsubsection{Localização e identificação}

Foram anotados: o número do indivíduo, com numeração crescente, contando também covas e indivíduos mortos; o nome da rua; o nome comum, o gênero e a espécie referentes ao indivíduo.

\subsubsection{Biologia}

\section{a) Estado geral}

Para se determinar o estado geral de cada indivíduo, foram consideradas as seguintes características:

- Ótimo: indivíduo plenamente vigoroso e sadio, sem sinais de ataque de pragas, doenças ou injúrias mecânicas, mantendo suas características arquitetônicas.

- Bom: indivíduo com boas condições gerais de vigor e saúde, podendo apresentar algum sinal de deficiência superficial, ataque de pragas ou doenças, ou injúria mecânica superficial, porém em bom estado.

- Regular: indivíduo em início de declínio, podendo apresentar ataque severo de pragas, doenças, ou injúrias mecânicas, descaracterizando sua arquitetura, desequilibrando o vegetal ou ainda apresentando deficiência.

- Péssimo: indivíduo em estado avançado e irreversível de declínio, com ataque ou dano intenso de pragas, doenças, deficiências, prejudicando a função do indivíduo na arborização e causando risco de queda ou morte do vegetal.

- Morta: indivíduo morto ou em estado de morte iminente, perdendo a função na arborização.

\section{b) Equilíbrio geral}

- Equilibrada - com eixo simétrico

- Desequilibrada - com eixo assimétrico 
Atentou-se para essas características dos indivíduos no nível do caule e no nível da copa, ou em ambos.

\section{c) Aspectos fitossanitários}

Verificou-se a olho nu, a presença de pulgão, broca, cupim, formiga, lagarta, cochonilha, vaquinha e a presença de doenças.

\section{d) Intensidade}

$\mathrm{Na}$ medida em que se verificou qualquer tipo de ataque, este foi classificado em:

- Leve: sem dano para o vigor e função do indivíduo;

- Médio: apresenta pequeno comprometimento no seu vigor;

- Pesado: comprometimento sério do indivíduo.

\section{e) Local/ataque}

Foi anotada a parte do indivíduo que foi afetada: caule, raiz, frutos, flores, ramos e/ou folhas.

\section{f) Injúrias}

Detectada qualquer injúria, esta foi classificada em:

- Lesão grave: compromete a sobrevivência do indivíduo;

- Lesão média: o indivíduo pode ser recuperado, mediante ações;

- Lesão leve: a injúria é de pequena proporção;

- Vandalismo: injúrias por vândalos.

\section{g) Ecologia}

Observou-se também a presença de insetos, ninhos, hemiparasitas e líquens. 


\section{h) Fenologia}

Atentou-se para os fenômenos periódicos dos indivíduo, ou seja, qual parte vegetal estava presente durante o levantamento: folha, flor e/ou fruto.

\subsubsection{Entorno e interferências}

\section{a) Localização geral}

No canteiro central, na calçada, ou leito carrocável.

\section{b) Localização relativa}

Junto a guia da calçada, junto a divisa do lote ou centrada na calçada.

\section{c) Pavimento da calçada}

Terra, cimento, pedra, cerâmica ou grama.

\section{d) Afloramento de raiz}

Na calçada, no canteiro, no leito carroçável e/ou na construção.

\section{e) Participação}

- Isolada - apenas um indivíduo da espécie isolada

- Duas ou mais - mais do que um indivíduo da mesma espécie próximos

\section{f) Tipo de fiação}

De derivação, primária, secundária e/ou telefone.

\section{g) Recuo}

Existência ou não de recuo entre o indivíduo e a construção. 


\section{h) Situação adequada}

Indivíduo sem conflitos com equipamentos ou construções

\section{i) Manilha ou tubulação de concreto}

Verificação se está presente ou não.

\section{j) Colo pavimentado}

Sem área nenhuma ou pouquíssimo solo exposto, devido à pavimentação.

\section{1) Árvore dentro de imóvel}

Verificação se há ou não presença de árvore no interior de imóvel.

m) Fiação, posteamento, iluminação, sinalização, muro/construção

- Atual - quando o equipamento ou a edificação está em contato com o indivíduo

- Potencial - quando há probabilidade desse contato

- Ausente - não existe a possibilidade de contato

\subsubsection{Definições de ações}

\section{Ação executada e ação recomendada:}

Foram anotadas nas planilhas as ocorrências de ações previamente executadas como: poda leve, poda pesada, controle, substituição, plantio, reparos de danos e ampliação de canteiros. Essas ações foram analisadas em sua adequação, o que tornou possível especificar a sua qualidade. A partir desses dados, foram também apontadas as ações recomendadas para o futuro. É importante lembrar que tanto a análise como as recomendações constam nas planilhas. 


\subsubsection{Dimensões}

Nas planilhas quantitativas foram anotadas os seguintes dados: o número do indivíduo, o número do imóvel, a largura da calçada, a altura geral do indivíduo, a altura da primeira bifurcação, diâmetro da copa e a circunferência à altura do peito (CAP), onde foram anotados até 9 bifurcações por indivíduo. Quando o total de bifurcações ultrapassavam esse número, a circunferência era medida na área basal da planta, próxima ao solo. A partir da circunferência à altura do peito (CAP), calculou-se o diâmetro à altura do peito (DAP). Pela formula:

$\mathrm{DAP}=(\mathrm{CAP} 1 / \pi)+(\mathrm{CAP} 2 / \pi)+(\mathrm{CAP} 3 / \pi)+\ldots$

onde:

$\mathrm{DAP}=$ diâmetro à altura do peito $(\mathrm{m})$

$\mathrm{CAP}=$ circunferência à altura do peito $(\mathrm{m})$

\subsection{Análise dos dados}

O levantamento da arborização foi realizado ao longo de todo o mês de julho do ano de 2003. Apenas uma pessoa analisou e anotou os dados qualitativos de todo o trabalho, enquanto que os outros componentes do grupo anotaram os dados quantitativos, em planilhas separadas.

Os dados foram tabulados em um banco de dados do Microsoft ACCESS, elaborado por Silva Filho (2002).

Para o georreferenciamento do mapa da Estância de Águas de São Pedro, foi utilizado o TNT-Mips, onde foram medidos os comprimentos das vias públicas. 
Para o cálculo do índice de diversidade utilizou-se a função de ShannonWiener $^{5}$, citado por Coelho (2000):

$H=-\sum_{i=1}^{s}$ pi Ln pi

onde:

$\mathrm{H}=$ índice de Shannon,

$\mathrm{s}=$ número de espécies;

pi = proporção da amostra contendo indivíduos da espécie i.

E também a fórmula de Odum ${ }^{6}$ citado por Coelho (2000):

$\mathrm{d} 1=(\mathrm{S}-1) / \lg \mathrm{N}$

onde:

$\mathrm{d} 1$ = índice de diversidade

$\mathrm{S}=$ número total de espécies

$\mathrm{N}=$ somatória de abundâncias

${ }^{5}$ SHANNON, C.E.; WEAVER, W. The mathematical theory of communication. Urbana: University of Illinois Press, 1949.

${ }^{6}$ ODUM, E.P. Ecologia. 3.ed. México: Interamericana, 1972. 639 p. 


\section{RESULTADOS E DISCUSSÃO}

\subsection{Composição e distribuição das espécies}

No inventário da arborização viária da Estância de Águas de São Pedro, foram percorridos $30.176 \mathrm{~m}$ de ruas, avenidas e vielas, e analisados 3.654 indivíduos vivos (arbóreos, arbustivos, palmáceas e coníferas), 40 árvores mortas, 312 covas vazias, perfazendo-se um total de 4.005 planilhas catalogadas.

Na Tabela 1, observa-se a distribuição de todos os indivíduos cadastrados na arborização viária da Estância de Águas de São Pedro. Verificou-se que a espécie de maior prevalência observada é a Caesalpinia peltophoroides (sibipiruna), que constitui $13,63 \%$ da arborização. A título de comparação, observa-se que em Piracicaba as sibipirunas representaram 52,3\% das árvores da cidade (Lima, 1993); em Brasília a mesma espécie apresentou-se como a mais comum, com 6,97\% (Rodrigues et al., 1994); em Manaus a Licania tomentosa (oiti) contribuiu com 29\% da arborização (Costa \& Higuchi, 1999); em Campos de Jordão a espécie mais predominante, o Platanus acerifolia (plátano), representou 53,70\% da arborização (Andrade, 2002); em Jaboticabal a espécie Licania tomentosa (oiti) representou 21,58\% do total de árvores (Silva Filho, 2002).

Segundo Santamour Júnior (2002) a maior diversidade de espécies de árvores na paisagem urbana se faz necessária justamente para garantir o máximo de proteção contra pragas e doenças. Dessa forma, segundo o mesmo autor, recomenda-se não exceder mais que $10 \%$ da mesma espécie, $20 \%$ de algum gênero e $30 \%$ de uma família botânica. A Estância de Águas de São Pedro apresenta-se com apenas uma espécie 
que ultrapassa os 10\% desejáveis, a sibipiruna (Tabela 1); esse excedente, entretanto, não desqualifica o indivíduo arbóreo, na medida em que são reconhecidas suas funções ambientais, contudo, recomenda-se o plantio de outras espécies que apresentem semelhantes características ambientais, a fim de se preservá-la e diminuir sua freqüência; esse fato já é observado, mas sem a preocupação em relação às funções ambientais. Quanto ao gênero, não há nenhum com distribuição maior que $20 \%$ da arborização viária (Tabela 2)(Anexo C). O mesmo ocorre em relação à família, a medida em que nenhuma representa mais que 30\% da arborização viária (Tabela 3)(Anexo D), o que demonstra uma satisfatória distribuição na arborização viária.

$\mathrm{Na}$ arborização viária da Estância de Águas de São Pedro, várias espécies arbóreas, arbustivas, palmáceas e coníferas foram contempladas, perfazendo um total de 161 espécies (Tabela 1), 126 gêneros (Tabela 2) e 54 famílias (Tabela 3). Note-se que em Piracicaba, 35 espécies compunham a área estudada (Lima, 1993); em Manaus 78 espécies foram observadas (Costa \& Higuchi, 1999); em Brasília 214 espécies, sendo 55 famílias (Rodrigues et al., 1994); em Campos de Jordão apenas 32 espécies (Andrade, 2002); em Jaboticabal observou-se a presença de 116 espécies (Silva Filho, 2002) e na Orla de Santos, 65 espécies (Meneguetti, 2003). Ao se compararem esses dados, observa-se que, dentre essas cidades, somente Brasília possui mais espécies que a Estância de Águas de São Pedro.

A soma das porcentagens das dez espécies de maior freqüência da Estância de Águas de São Pedro corresponde a 48,33\% de toda a arborização viária; em Jaboticabal, as dez espécies mais freqüentes perfaziam $71,25 \%$ do total de indivíduos, o que indica uma melhor eqüidade de espécies na Estância de Águas de São Pedro em relação a essa cidade. Em Brasília, as treze espécies de maior freqüência representavam 48,3\% do total dos indivíduos encontrados (Rodrigues et al., 1994); em Piracicaba, as treze espécies de maior freqüência compunham 86,5\% da população (Lima et al., 1994). Observou-se, assim, que praticamente metade da arborização viária da Estância de Águas de São Pedro é composta por apenas dez espécies e que se pode, portanto, adequar melhor essa distribuição. 
Tabela 1. Distribuição quantitativa de cada espécie encontrada na arborização viária da Estância de Águas de São Pedro, segundo o nome comum, o nome científico, total de indivíduos e freqüência

\begin{tabular}{|c|c|c|c|}
\hline Nome Comum & Nome científico & Total & $\begin{array}{c}\text { Freqüência } \\
(\%)\end{array}$ \\
\hline Sibipiruna & Caesalpinia peltophoroides Benth. & 498 & 13.63 \\
\hline Flamboyant & Delonix regia (Bojer ex Hook.) Raf. & 215 & 5.88 \\
\hline Ficus-benjamim & Ficus benjamina L. & 186 & 5.09 \\
\hline Pata-de-vaca & Bauhinia variegata $\mathrm{L}$. & 158 & 4.32 \\
\hline Chapéu-de-sol & Terminalia catappa L. & 152 & 4.16 \\
\hline Hibisco & Hibiscus rosa-sinensis L. & 139 & 3.80 \\
\hline Areca-bambu & Dypsis lutescens H. Wendl. & 124 & 3.39 \\
\hline Oiti & Licania tomentosa (Benth.) Fritsch. & 99 & 2.71 \\
\hline Resedá & Lagerstroemia indica L. & 98 & 2.68 \\
\hline Espatódia & Spathodea nilotica Seem & 97 & 2.65 \\
\hline Falsa-murta & Murraya paniculata (L.) Jacq. & 86 & 2.35 \\
\hline *Ipê-roxo & Tabebuia sp & 84 & 2.30 \\
\hline Chuva-de-ouro & Cassia fistula $\mathrm{L}$. & 74 & 2.03 \\
\hline Ipê-amarelo-do-cerrado & Tabebuia chrysotricha (Mart. ex DC.) Stand. & 73 & 2.00 \\
\hline Quaresmeira & Tibouchina granulosa (Desc.) Cogn & 64 & 1.75 \\
\hline Mangueira & Mangifera indica L. & 56 & 1.53 \\
\hline Pingo-de-ouro & Duranta repens $\mathrm{L}$. & 55 & 1.51 \\
\hline Citrus & Citrus sp & 53 & 1.45 \\
\hline Espirradeira & Nerium oleander L. & 52 & 1.42 \\
\hline Primavera & Bougainvillea spectabilis Willd & 46 & 1.26 \\
\hline Tuia & Thuja occidentalis L. & 42 & 1.15 \\
\hline Pinos & Pinus elliotti Engel. & 41 & 1.12 \\
\hline Sabão-de-soldado & Sapindus saponaria $\mathrm{L}$. & 41 & 1.12 \\
\hline Tipuana & Tipuana tipu (Benth.) Kuntze & 41 & 1.12 \\
\hline Cróton & Codiaeum variegatum Blume & 37 & 1.01 \\
\hline Alfeneiro & Ligustrum lucidum W. T. Aiton & 35 & 0.96 \\
\hline Alecrim-de-campinas & Holocalyx balansae Mich. & 34 & 0.93 \\
\hline Falso-chorão & Schinus molle $\mathrm{L}$. & 34 & 0.93 \\
\hline Ipê-branco & Tabebuia roseo-alba (Ridl.) Sandw. & 34 & 0.93 \\
\hline Goiabeira & Psidium guajava L. & 32 & 0.88 \\
\hline Pitangueira & Eugenia uniflora L. & 30 & 0.82 \\
\hline Magnólia-amarela & Michelia champaca L. & 29 & 0.79 \\
\hline Coqueiro-da-bahia & Cocos nucifera $\mathrm{L}$. & 28 & 0.77 \\
\hline Pau-brasil & Caesalpinia echinata Lam. & 27 & 0.74 \\
\hline Aroeira-pimenteira & Schinus terebinthifolius Raddi & 26 & 0.71 \\
\hline Ipê-rosa-americano & Tabebuia pentaphylla Hemsl. & 26 & 0.71 \\
\hline Pata-de-vaca-branca & Bauhinia variegata L. var. candida & 26 & 0.71 \\
\hline Grevilha & Grevillea robusta A. Cunn. Ex. R. Br. & 25 & 0.68 \\
\hline Jacarandá-mimoso & Jacaranda mimosaefolia D. Don & 25 & 0.68 \\
\hline
\end{tabular}


Tabela 1. Distribuição quantitativa de cada espécie encontrada na arborização viária da Estância de Águas de São Pedro, segundo o nome comum, o nome científico, total de indivíduos e freqüência

\begin{tabular}{|c|c|c|c|}
\hline Nome Comum & Nome científico & Total & $\begin{array}{c}\text { Freqüência } \\
(\%)\end{array}$ \\
\hline Ficus-variegata & Ficus benjamina L. var. variegata & 23 & 0.63 \\
\hline Amoreira & Morus nigra L. & 20 & 0.55 \\
\hline Jaboticabeira & Myrciaria trunciflora Berg. & 19 & 0.52 \\
\hline Jasmim-manga & Plumeria rubra L. & 19 & 0.52 \\
\hline Lanterna-japonesa & Koelreuteria elegans (Seem.) A.C.Sm. & 19 & 0.52 \\
\hline Dracena roxa & Cordyline terminalis Kunth & 18 & 0.49 \\
\hline Ipê-mirim & Stenolobium stans (L.) Seem. & 18 & 0.49 \\
\hline Palmeira-real & Roystonea regia (H. B. K.) O. F. Cook & 18 & 0.49 \\
\hline Mirindiba & Lafoensia glyptocarpa Koehne & 17 & 0.47 \\
\hline Mussaenda & Mussaenda erythrophylla Schum. \& Thonning & 17 & 0.47 \\
\hline Abacateiro & Persea americana L. & 16 & 0.44 \\
\hline Chapéu-de-napoleão & Thevetia peruviana K. Schum. & 16 & 0.44 \\
\hline Jerivá & Syagrus romanzoffiana (Cham.) Glassm. & 16 & 0.44 \\
\hline Santa-bárbara & Melia azedarach L. & 16 & 0.44 \\
\hline Acerola & Malpighia punicifolia L. & 15 & 0.41 \\
\hline Pau-ferro & Caesalpinia ferrea Mart. ex Tul. var. leiostachya Benth. & 15 & 0.41 \\
\hline Cipreste-do-mediterrâneo & Cupressus sempervirens L. & 13 & 0.36 \\
\hline Nêspera & Eriobotrya japonica (Thunb.) Lind. & 12 & 0.33 \\
\hline Flamboyant-de-jardim & Caesalpinia pulcherrima Sw. & 12 & 0.33 \\
\hline Palmeira-imperial & Roystonea oleracea (N. J. Jacquin) O. F. Cook & 12 & 0.33 \\
\hline Palmeira-leque & Livistonia chinensis (N. J. Jacquin) R. Brown ex Mart & 10 & 0.27 \\
\hline Cabeça-de-velho & Euphorbia leucocephala Lotsy & 9 & 0.25 \\
\hline Calabura & Muntingia calabura $\mathrm{L}$. & 9 & 0.25 \\
\hline Grevilha-anã & Grevillea banksii R. Br. & 9 & 0.25 \\
\hline Leucena & Leucena leucocephala (Lam.) R. de Wit & 9 & 0.25 \\
\hline Manacá-de-jardim & Brunfelsia uniflora D. Don. & 8 & 0.22 \\
\hline Pata-de-vaca-púrpura & Bauhinia blakeana Dunn & 8 & 0.22 \\
\hline Tuia-aurea & Thuja sp & 8 & 0.22 \\
\hline Astrapéia & Dombeya wallichii (Lindl.) K. Schum. & 7 & 0.19 \\
\hline Canelinha & Nectandra megapotamica (Spreng.) Mez & 7 & 0.19 \\
\hline Paineira & Chorisia speciosa St. Hil. & 7 & 0.19 \\
\hline Queureuteria & Koelreuteria paniculata (Seem.) A.C.Sm. & 7 & 0.19 \\
\hline Tuia-kaizuca & Juniperus chinensis L. & 7 & 0.19 \\
\hline Palmeira-veitchia & Veitchia sp & 6 & 0.16 \\
\hline Ficus-microcarpa & Ficus microcarpa L.f. & 5 & 0.14 \\
\hline Jambolão & Syzygium cuminii (L.) Skeels & 5 & 0.14 \\
\hline Munguba & Pachira aquatica Aubl. & 5 & 0.14 \\
\hline Peroba-rosa & Aspidosperma polyneuron M. Arg. & 5 & 0.14 \\
\hline Quaresmeira-arbustiva & Tibouchina semidecandra (DC.) Cogn & 5 & 0.14 \\
\hline
\end{tabular}


Tabela 1. Distribuição quantitativa de cada espécie encontrada na arborização viária da Estância de Águas de São Pedro, segundo o nome comum, o nome científico, total de indivíduos e freqüência

\begin{tabular}{|c|c|c|c|}
\hline Nome Comum & Nome científico & Total & $\begin{array}{c}\text { Freqüência } \\
\text { (\%) }\end{array}$ \\
\hline Romãzeiro & Punica granatum $\mathrm{L}$. & 5 & 0.14 \\
\hline Araucária & Araucaria columnaris (Forst.) Hook. & 4 & 0.11 \\
\hline Azaléia & Rhododendron simsii Planch. & 4 & 0.11 \\
\hline Azeitona-do-ceilão & Elaeocarpus serratus $L$. & 4 & 0.11 \\
\hline Cheflera & Schefflera arboricola (Hayata) Merr. & 4 & 0.11 \\
\hline Esponja & Calliandra brevipes Benth. & 4 & 0.11 \\
\hline Ixora & Ixora coccinea $\mathrm{L}$. & 4 & 0.11 \\
\hline Mamoeiro & Carica papaya $\mathrm{L}$. & 4 & 0.11 \\
\hline Tamarindo & Tamarindus indica $\mathrm{L}$. & 4 & 0.11 \\
\hline Camelia & Camellia japonica L. & 3 & 0.08 \\
\hline Dama-da-noite-intemediária & Cestrum intermedium Sendt. & 3 & 0.08 \\
\hline Dedaleira & Lafoensia pacari St. Hil. & 3 & 0.08 \\
\hline Escovinha-de-garrafa & Callistemon viminalis (Sol. ex. Gaertn.) G. Don ex Loud. & 3 & 0.08 \\
\hline Eugenia & Eugenia sprengelli DC. & 3 & 0.08 \\
\hline Figueira & Ficus sp & 3 & 0.08 \\
\hline Guaçatonga & Casearia sylvestris $\mathrm{Sw}$. & 3 & 0.08 \\
\hline Guanandi & Calophyllum brasiliensis Camb. & 3 & 0.08 \\
\hline Jacarandá-branco & Platypodium elegans Vog. & 3 & 0.08 \\
\hline Jamelão & Syzygium jambos (L.) Alston & 3 & 0.08 \\
\hline Jequitibá-rosa & Cariniana legalis (Mart.) Kuntze & 3 & 0.08 \\
\hline Leiteira-roxa & Euphorbia cotinifolia L. & 3 & 0.08 \\
\hline Lofântera & Lophanthera lactescens Ducke & 3 & 0.08 \\
\hline Palmeira rabo-de-peixe & Caryota urens L. & 3 & 0.08 \\
\hline Pata-de-vaca-do-mato & Bauhinia forficata Link & 3 & 0.08 \\
\hline Sirigüela & Spondias purpurea L. & 3 & 0.08 \\
\hline Sombreiro & Clitoria fairchildiana R. A. Howard & 3 & 0.08 \\
\hline Acacia & Acacia mangium Willd. & 2 & 0.05 \\
\hline Bananeira & Musa sp & 2 & 0.05 \\
\hline Brauna & Melanoxylon brauna Schott & 2 & 0.05 \\
\hline Canafístula & Peltophorum dubium (Spreng.) Taub. & 2 & 0.05 \\
\hline Castanha-do-maranhão & Bombacopsis glabra (Pasq.) A. Rob. & 2 & 0.05 \\
\hline Chorão & Salix babylonica L. & 2 & 0.05 \\
\hline Cicas & Cycas circinalis L. & 2 & 0.05 \\
\hline Clerodendron & Clerodendron $s p$ & 2 & 0.05 \\
\hline Dama-da-noite & Cestrum nocturnum L. & 2 & 0.05 \\
\hline Melaleuca & Melaleuca leucadendron (L.) L. & 2 & 0.05 \\
\hline Mil-cores & Breynia nivosa Small & 2 & 0.05 \\
\hline Nogueira-de-iguape & Aleurites moluccana (L.) Willd. & 2 & 0.05 \\
\hline
\end{tabular}


Tabela 1. Distribuição quantitativa de cada espécie encontrada na arborização viária da Estância de Águas de São Pedro, segundo o nome comum, o nome científico, total de indivíduos e freqüência

\begin{tabular}{|c|c|c|c|}
\hline Nome Comum & Nome científico & Total & $\begin{array}{c}\text { Freqüência } \\
(\%)\end{array}$ \\
\hline Pau-formiga & Triplaris americana $\mathrm{L}$. & 2 & 0.05 \\
\hline Fênix & Phoenix canariensis Hort. ex Chabaud & 2 & 0.05 \\
\hline Pinha & Annona squamosa $\mathrm{L}$. & 2 & 0.05 \\
\hline Sena & Senna macranthera (Collad.) Irwin et Barneby & 2 & 0.05 \\
\hline Tamareira-anã & Phoenix roebelenii O`Brien & 2 & 0.05 \\
\hline Tento-carolina & Adenanthera pavonina L. & 2 & 0.05 \\
\hline Uva-japonesa & Hovenia dulcis Thunb. & 2 & 0.05 \\
\hline Acacia-mimosa & Acacia podalyraefolia A. Cunn. Ex G. Don & 1 & 0.03 \\
\hline Pinheiro-de-Kauri & Agathis robusta (C. Moore) F. M. Bailey & 1 & 0.03 \\
\hline Alamanda & Allamanda laevis Markgr. & 1 & 0.03 \\
\hline Alucinógeno & Psychotria carthagenensis Jacq. & 1 & 0.03 \\
\hline Bico-de-papagaio & Euphorbia pulcherrima Willd. Ex Klotzsch & 1 & 0.03 \\
\hline Bigueiro & Albizia lebbeck (L.) Benth. & 1 & 0.03 \\
\hline Brassaia & Schefflera actinophylla Harms & 1 & 0.03 \\
\hline Cabeludinha & Plinia glomerata (Berg.) Amsh. & 1 & 0.03 \\
\hline Cabreúva & Myroxylon peruiferum L.f. & 1 & 0.03 \\
\hline Cafeeiro & Coffea arabica $\mathrm{L}$. & 1 & 0.03 \\
\hline Cajueiro & Anacardium occidentale $\mathrm{L}$. & 1 & 0.03 \\
\hline Cassia & Cassia javanica L. & 1 & 0.03 \\
\hline Cedro & Cedrela fissilis Vell. & 1 & 0.03 \\
\hline Cerejeira-do-japão & Prunus serrulata Lindl. & 1 & 0.03 \\
\hline Chapéu-de-couro & Ficus lyrata Warb. & 1 & 0.03 \\
\hline Copaíba & Copaifera langsdorffii Desf. & 1 & 0.03 \\
\hline Embaúba & Cecropia hololeuca Miq. & 1 & 0.03 \\
\hline Embauba-vermelha & Cecropia glaziovii Snethlage & 1 & 0.03 \\
\hline Suinã & Erythrina speciosa Andrews & 1 & 0.03 \\
\hline Espinheira-santa & Maytenus ilicifolia Mart. ex. Reiss. & 1 & 0.03 \\
\hline Espiraea & Spiraea $s p$ & 1 & 0.03 \\
\hline Figueira-branca & Ficus guaranitica Schodat & 1 & 0.03 \\
\hline Garcínia & Garcinia sp & 1 & 0.03 \\
\hline Iuca & Yucca elephantipes Regel. & 1 & 0.03 \\
\hline Jambo-branco & Syzygium aqueum (Burm.f.) Alston & 1 & 0.03 \\
\hline Jambo-vermelho & Syzygium malaccense (L.) Merr. \& L.M. Perry & 1 & 0.03 \\
\hline Lea & Leea rubra Blume & 1 & 0.03 \\
\hline Macadamia & Macadamia integrifolia Maiden \& Betch & 1 & 0.03 \\
\hline Malvavisco & Malvaviscus arboreus Cav. & 1 & 0.03 \\
\hline Manacá-da-serra & Tibouchina pulchra (Cham.) & 1 & 0.03 \\
\hline Mogno & Swietenia sp & 1 & 0.03 \\
\hline Pecan & Carya illinoinensis (Wangenh.) C. Koch & 1 & 0.03 \\
\hline
\end{tabular}


Tabela 1. Distribuição quantitativa de cada espécie encontrada na arborização viária da Estância de Águas de São Pedro, segundo o nome comum, o nome científico, total de indivíduos e freqüência

\begin{tabular}{|c|c|c|c|}
\hline Nome Comum & Nome científico & Total & $\begin{array}{c}\text { Freqüência } \\
(\%)\end{array}$ \\
\hline Pessegueiro-do-mato & Psidium cattleyanum Sabine & 1 & 0.03 \\
\hline Plátano & Platanus cf. orientalis (Aiton) Willd. & 1 & 0.03 \\
\hline Roseira & Rosa $\times$ grandiflora Hort & 1 & 0.03 \\
\hline Sabugueiro & Sambucus nigra L. & 1 & 0.03 \\
\hline Sapucaia & Lecythis pisonis Camb. & 1 & 0.03 \\
\hline Tuia-holandesa & Cupressus macrocarpa Hartw. & 1 & 0.03 \\
\hline Uvaia & Eugenia pyriformis Camb. & 1 & 0.03 \\
\hline
\end{tabular}


Tabela 2. Distribuição quantitativa dos gêneros na arborização viária da Estância de Águas de São Pedro-SP

\begin{tabular}{|c|c|c|}
\hline Gênero & Total & Freqüência (\%) \\
\hline Caesalpinia & 552 & 15.11 \\
\hline Ficus & 219 & 6.00 \\
\hline Tabebuia & 217 & 5.94 \\
\hline Delonix & 215 & 5.89 \\
\hline Bauhinia & 195 & 5.34 \\
\hline Terminalia & 152 & 4.16 \\
\hline Hibiscus & 139 & 3.81 \\
\hline Dypsis & 124 & 3.39 \\
\hline Licania & 99 & 2.71 \\
\hline Lagerstroemia & 98 & 2.68 \\
\hline Spathodea & 97 & 2.66 \\
\hline Murraya & 86 & 2.35 \\
\hline Cassia & 75 & 2.05 \\
\hline Tibouchina & 70 & 1.92 \\
\hline Schinus & 60 & 1.64 \\
\hline Mangifera & 56 & 1.53 \\
\hline Duranta & 55 & 1.51 \\
\hline Citrus & 53 & 1.45 \\
\hline Nerium & 52 & 1.42 \\
\hline Bougainvillea & 46 & 1.26 \\
\hline Tuia & 42 & 1.15 \\
\hline Pinus & 41 & 1.12 \\
\hline Tipuana & 41 & 1.12 \\
\hline Sapindus & 41 & 1.12 \\
\hline Codieaum & 37 & 1.01 \\
\hline Ligustrum & 35 & 0.96 \\
\hline Eugenia & 34 & 0.93 \\
\hline Holocalyx & 34 & 0.93 \\
\hline Grevillea & 34 & 0.93 \\
\hline Psidium & 33 & 0.90 \\
\hline Roystonea & 30 & 0.82 \\
\hline Michelia & 29 & 0.79 \\
\hline Cocos & 28 & 0.77 \\
\hline Koelreuteria & 26 & 0.71 \\
\hline Jacaranda & 25 & 0.68 \\
\hline Morus & 20 & 0.55 \\
\hline Lafoensia & 20 & 0.55 \\
\hline Myrciaria & 19 & 0.52 \\
\hline Plumeria & 19 & 0.52 \\
\hline Cordyline & 18 & 0.49 \\
\hline Stenolobium & 18 & 0.49 \\
\hline Mussaenda & 17 & 0.47 \\
\hline Persea & 16 & 0.44 \\
\hline Melia & 16 & 0.44 \\
\hline
\end{tabular}


Tabela 2. Distribuição quantitativa dos gêneros na arborização viária da Estância de Águas de São Pedro-SP

\begin{tabular}{|c|c|c|}
\hline Gênero & Total & Freqüência (\%) \\
\hline Syagrus & 16 & 0.44 \\
\hline Thevetia & 16 & 0.44 \\
\hline Malpighia & 15 & 0.41 \\
\hline Cupressus & 14 & 0.38 \\
\hline Euphorbia & 13 & 0.36 \\
\hline Eriobotrya & 12 & 0.33 \\
\hline Livistona & 10 & 0.27 \\
\hline Syzygium & 10 & 0.27 \\
\hline Leucena & 9 & 0.25 \\
\hline Muntingia & 9 & 0.25 \\
\hline Thuja & 8 & 0.22 \\
\hline Brunfelsia & 8 & 0.22 \\
\hline Juniperus & 7 & 0.19 \\
\hline Chorisia & 7 & 0.19 \\
\hline Dombeya & 7 & 0.19 \\
\hline Nectandra & 7 & 0.19 \\
\hline Veitchia & 6 & 0.16 \\
\hline Punica & 5 & 0.14 \\
\hline Aspidosperma & 5 & 0.14 \\
\hline Cestrum & 5 & 0.14 \\
\hline Pachira & 5 & 0.14 \\
\hline Schefflera & 5 & 0.14 \\
\hline Elaeocarpus & 4 & 0.11 \\
\hline Calliandra & 4 & 0.11 \\
\hline Carica & 4 & 0.11 \\
\hline Phoenix & 4 & 0.11 \\
\hline Ixora & 4 & 0.11 \\
\hline Araucaria & 4 & 0.11 \\
\hline Tamarindus & 4 & 0.11 \\
\hline Rhododendron & 4 & 0.11 \\
\hline Callistemon & 3 & 0.08 \\
\hline Clitoria & 3 & 0.08 \\
\hline Platypodium & 3 & 0.08 \\
\hline Calophyllum & 3 & 0.08 \\
\hline Acacia & 3 & 0.08 \\
\hline Camellia & 3 & 0.08 \\
\hline Cariniana & 3 & 0.08 \\
\hline Lophanthera & 3 & 0.08 \\
\hline Casearia & 3 & 0.08 \\
\hline Caryota & 3 & 0.08 \\
\hline Spondias & 3 & 0.08 \\
\hline Cecropia & 2 & 0.05 \\
\hline Senna & 2 & 0.05 \\
\hline Clerodendron & 2 & 0.05 \\
\hline
\end{tabular}


Tabela 2. Distribuição quantitativa dos gêneros na arborização viária da Estância de Águas de São Pedro-SP

\begin{tabular}{|c|c|c|}
\hline Gênero & Total & Freqüência (\%) \\
\hline Adenanthera & 2 & 0.05 \\
\hline Salix & 2 & 0.05 \\
\hline Triplaris & 2 & 0.05 \\
\hline Melaleuca & 2 & 0.05 \\
\hline Cycas & 2 & 0.05 \\
\hline Aleurites & 2 & 0.05 \\
\hline Peltophorum & 2 & 0.05 \\
\hline Annona & 2 & 0.05 \\
\hline Musa & 2 & 0.05 \\
\hline Melanoxylon & 2 & 0.05 \\
\hline Bombacopsis & 2 & 0.05 \\
\hline Breynia & 2 & 0.05 \\
\hline Hovenia & 2 & 0.05 \\
\hline Albizia & 1 & 0.03 \\
\hline Allamanda & 1 & 0.03 \\
\hline Anacardium & 1 & 0.03 \\
\hline Agathis & 1 & 0.03 \\
\hline Macadamia & 1 & 0.03 \\
\hline Swietenia & 1 & 0.03 \\
\hline Sambucus & 1 & 0.03 \\
\hline Rosa & 1 & 0.03 \\
\hline Psychotria & 1 & 0.03 \\
\hline Prunus & 1 & 0.03 \\
\hline Plinia & 1 & 0.03 \\
\hline Platanus & 1 & 0.03 \\
\hline Myroxylon & 1 & 0.03 \\
\hline Lea & 1 & 0.03 \\
\hline Malvaviscus & 1 & 0.03 \\
\hline Carya & 1 & 0.03 \\
\hline Yucca & 1 & 0.03 \\
\hline Lecythis & 1 & 0.03 \\
\hline Garcinia & 1 & 0.03 \\
\hline Spiraea & 1 & 0.03 \\
\hline Erythrina & 1 & 0.03 \\
\hline Copaifera & 1 & 0.03 \\
\hline Coffea & 1 & 0.03 \\
\hline Cedrela & 1 & 0.03 \\
\hline Maytenus & 1 & 0.03 \\
\hline
\end{tabular}


Tabela 3. Distribuição quantitativa das famílias na arborização viária da Estância de Águas de São Pedro-SP

\begin{tabular}{|c|c|c|}
\hline Família & Total & Freqüência (\%) \\
\hline LEGUMINOSAE-CAESALPINIOIDEAE & 867 & 23.73 \\
\hline BIGNONIACEAE & 357 & 9.77 \\
\hline MORACEAE & 240 & 6.57 \\
\hline LEGUMINOSAE-MIMOSOIDEAE & 227 & 6.21 \\
\hline ARECACEAE & 211 & 5.78 \\
\hline COMBRETACEAE & 152 & 4.16 \\
\hline MALVACEAE & 140 & 3.83 \\
\hline RUTACEAE & 139 & 3.81 \\
\hline ANARCARDIACEAE & 120 & 3.28 \\
\hline LYTHRACEAE & 118 & 3.23 \\
\hline MYRTACEAE & 101 & 2.76 \\
\hline CHRYSOBALANACEAE & 99 & 2.71 \\
\hline APOCYNACEAE & 93 & 2.55 \\
\hline CUPRESSACEAE & 71 & 1.94 \\
\hline MELASTOMATACEAE & 70 & 1.92 \\
\hline SAPINDACEAE & 67 & 1.83 \\
\hline VERBENACEAE & 57 & 1.56 \\
\hline LEGUMINOSAE-PAPILIONOIDEAE & 57 & 1.56 \\
\hline EUPHORBIACEAE & 54 & 1.48 \\
\hline NYCTAGINACEAE & 46 & 1.26 \\
\hline PINACEAE & 41 & 1.12 \\
\hline LAURACEAE & 41 & 1.12 \\
\hline PROTEACEAE & 35 & 0.96 \\
\hline OLEACEAE & 35 & 0.96 \\
\hline MAGNOLIACEAE & 32 & 0.88 \\
\hline RUBIACEAE & 23 & 0.63 \\
\hline MELIACEAE & 18 & 0.49 \\
\hline MALPIGHIACEAE & 18 & 0.49 \\
\hline ROSACEAE & 15 & 0.41 \\
\hline BOMBACACEAE & 14 & 0.38 \\
\hline ELAEOCARPACEAE & 13 & 0.36 \\
\hline SOLANACEAE & 13 & 0.36 \\
\hline PALMAE & 10 & 0.27 \\
\hline STERCULIACEAE & 7 & 0.19 \\
\hline ERICACEAE & 5 & 0.14 \\
\hline PUNICACEAE & 5 & 0.14 \\
\hline ARALIACEAE & 5 & 0.14 \\
\hline ARAUCARIACEAE & 5 & 0.14 \\
\hline CARICACEAE & 4 & 0.11 \\
\hline LECYTHIDACEAE & 4 & 0.11 \\
\hline FLACOURTIACEAE & 3 & 0.08 \\
\hline CLUSIACEAE & 3 & 0.08 \\
\hline CYCADACEAE & 2 & 0.05 \\
\hline ANNONACEAE & 2 & 0.05 \\
\hline
\end{tabular}


Tabela 3. Distribuição quantitativa das famílias na arborização viária da Estância de Águas de São Pedro-SP

\begin{tabular}{lcc}
\hline Família & Total & Freqüência (\%) \\
\hline RHAMNACEAE & 2 & 0.05 \\
JUGLANDACEAE & 2 & 0.05 \\
MUSACEAE & 2 & 0.05 \\
POLYGONACEAE & 2 & 0.05 \\
SALICACEAE & 2 & 0.05 \\
ACERACEAE & 1 & 0.03 \\
LILIACEAE & 1 & 0.03 \\
CELASTRACEAE & 1 & 0.03 \\
CECROPIACEAE & 1 & 0.03 \\
LEEACEAE & 1 & 0.03 \\
\hline
\end{tabular}

À partir dos dados inventariados, calculou-se um índice de indivíduos por quilometragem de rua para cada via pública percorrida, de acordo com seu comprimento e número total de indivíduos encontrados (Tabela 4).

Foi obtido também um índice médio para a Estância de Águas de São Pedro de 130 indivíduos por quilômetro de rua percorrida; em Manaus observou-se 20 árvores por quilômetro de rua (Costa \& Higuchi, 1999); em Campos de Jordão constatou-se 17,22 árvores por quilômetro de rua (Andrade, 2002). A comparação desses dados mostra que a Estância de Águas de São Pedro possui, em relação a essas cidades, um elevado índice por quilometragem. Deve-se ressaltar, porém, o fato de que esse levantamento não incluir apenas árvores, mas também arbustos.

Nota-se que as Avenidas Carlos Mauro S. de Moura e Antonio Joaquim de M. Andrade, apresentaram os maiores comprimentos e possuem as maiores quantidades de indivíduos cadastrados. A justificativa para tal talvez seja o fato de serem antigas na cidade e, portanto, contarem com maiores contribuições de plantios, ao longo do tempo. Essas avenidas possuem também um índice adequado por quilometragem (Tabela 4).

Obteve-se, porém, o maior índice por quilometragem na Rua dos Bentivis (472 indivíduos por quilômetro), devido à expressiva quantidade de Ficus benjamina (ficusbenjamin) e Pinus elliotti (pinos), índice este, maior que as avenidas citadas anteriormente com 131 e 104, respectivamente (Tabela 4). 
Tabela 4. Número total e índice de indivíduos por quilômetro de cada via pública da Estância de Águas de São Pedro, com respectivos comprimentos

\begin{tabular}{|c|c|c|c|}
\hline Nome da via pública & Comprimento (m) & Total & Índice de indivíduos /Km \\
\hline $55, \mathrm{r}$ & 55 & 2 & 36 \\
\hline $84, \mathrm{r}$ & 265 & 30 & 113 \\
\hline $85, \mathrm{r}$ & 55 & 9 & 164 \\
\hline Albano Bispo dos Santos, $r$ & 452 & 22 & 49 \\
\hline Amélio Scaranello, $r$ & 153 & 11 & 72 \\
\hline Amor Perfeito, $r$ & 132 & 4 & 30 \\
\hline Anna Brandini Mazziero, $r$ & 274 & 38 & 139 \\
\hline Antonio A. Barbosa, r & 246 & 56 & 228 \\
\hline Antonio Albino Ribeiro, $r$ & 320 & 71 & 222 \\
\hline Antonio Aparecido Gaiani, vl & 233 & 7 & 30 \\
\hline Antonio Casarini, $\mathrm{r}$ & 83 & 6 & 72 \\
\hline Antonio Feijó, r & 277 & 5 & 18 \\
\hline Antonio Joaquim de M. Andrade, av & 3269 & 429 & 131 \\
\hline Araci Algodoal Mauro, $\mathrm{r}$ & 670 & 114 & 170 \\
\hline Armando Brandini, $r$ & 273 & 32 & 117 \\
\hline Bela Vista, $r$ & 269 & 26 & 97 \\
\hline Carlos Mauro S. de Moura, av & 1284 & 133 & 104 \\
\hline Cesar Brunossi, $r$ & 117 & 10 & 85 \\
\hline das Acácias, $r$ & 252 & 34 & 135 \\
\hline das Andorinhas, $r$ & 144 & 39 & 271 \\
\hline das Araucárias, $\mathrm{r}$ & 476 & 64 & 134 \\
\hline das Azaléias, $\mathrm{r}$ & 268 & 48 & 179 \\
\hline das Camélias, $\mathrm{r}$ & 457 & 57 & 125 \\
\hline das Figueiras, $r$ & 109 & 6 & 55 \\
\hline das Hortências, $r$ & 289 & 42 & 145 \\
\hline das Margaridas, $r$ & 465 & 60 & 129 \\
\hline das Paineiras, $\mathrm{r}$ & 118 & 21 & 178 \\
\hline das Perobas, $\mathrm{r}$ & 73 & 14 & 192 \\
\hline das Primaveras, $r$ & 106 & 25 & 236 \\
\hline das Rosas, $r$ & 465 & 72 & 155 \\
\hline das Tulipas, $r$ & 610 & 20 & 33 \\
\hline dos Beija-Flores, $r$ & 193 & 12 & 62 \\
\hline dos Bentivis, $r$ & 125 & 59 & 472 \\
\hline dos Cedros, $r$ & 157 & 15 & 96 \\
\hline dos Curiós, $r$ & 81 & 23 & 284 \\
\hline dos Flamboyants, $r$ & 103 & 4 & 39 \\
\hline dos Gerâneos, r & 460 & 118 & 257 \\
\hline dos Jequitibás, $r$ & 60 & 16 & 267 \\
\hline dos Juritis, r & 54 & 1 & 19 \\
\hline dos Lírios, r & 509 & 59 & 116 \\
\hline dos Paus Brasis, $r$ & 406 & 17 & 42 \\
\hline dos Pinheiros, $r$ & 795 & 44 & 55 \\
\hline
\end{tabular}


Tabela 4. Número total e índice de indivíduos por quilômetro de cada via pública da Estância de Águas de São Pedro, com respectivos comprimentos

\begin{tabular}{|c|c|c|c|}
\hline Nome da via pública & Comprimento (m) & Total & Índice de indivíduos /Km \\
\hline dos Pintassilgos, $r$ & 171 & 16 & 94 \\
\hline dos Rouxinóis, $r$ & 472 & 17 & 36 \\
\hline dos Sabiás, $r$ & 579 & 118 & 204 \\
\hline Egídio Piccoli, $r$ & 607 & 18 & 30 \\
\hline Embaixador Oswaldo Aranha, r & 441 & 91 & 206 \\
\hline Emílio Marozzi, $r$ & 500 & 7 & 14 \\
\hline Engenheiro João Baloni, $r$ & 145 & 27 & 186 \\
\hline Ernesto Giocondo, $\mathrm{r}$ & 637 & 110 & 173 \\
\hline Favorino Prado Filho, r & 520 & 4 & 8 \\
\hline Francisco D. Scaranello, r & 188 & 22 & 117 \\
\hline Giomar S. de Moura Andrade, $r$ & 517 & 93 & 180 \\
\hline Hermínio Zampieri, r & 390 & 110 & 282 \\
\hline Horácio Mendes, r & 374 & 72 & 193 \\
\hline Iracema B. Andrade, vl & 280 & 26 & 93 \\
\hline Isaura de O. Algodoal, r & 288 & 46 & 160 \\
\hline João B. Baltieri, r & 138 & 10 & 72 \\
\hline João Baiani, r & 457 & 103 & 225 \\
\hline João Barbosa, r & 261 & 41 & 157 \\
\hline João Batista Azevedo, r & 137 & 15 & 109 \\
\hline João do O. Algodoal, r & 353 & 65 & 184 \\
\hline João Tardivelli, $r$ & 191 & 29 & 152 \\
\hline Joviano Mouer, $r$ & 580 & 49 & 84 \\
\hline Julius Boshard, r & 282 & 16 & 57 \\
\hline Laudelino Jorge de Moraes, $r$ & 414 & 64 & 155 \\
\hline Lecticia Fontabelli Marozzi, r & 286 & 70 & 245 \\
\hline Manuel Garcia, r & 268 & 5 & 19 \\
\hline Marechal Humberto de A. Castelo, r & 868 & 83 & 96 \\
\hline Maria D. Ribeiro Mazziero, $r$ & 365 & 24 & 66 \\
\hline Maria J.L. Carreta, r & 180 & 44 & 244 \\
\hline Martins Fontes, $r$ & 174 & 34 & 195 \\
\hline Maximiano Santin, $r$ & 266 & 31 & 117 \\
\hline Patrício Miguel Carreta, $\mathrm{r}$ & 152 & 9 & 59 \\
\hline Pedro Boscariol Sobrinho, $r$ & 219 & 52 & 237 \\
\hline Presidente John Kennedy, av & 1294 & 46 & 36 \\
\hline Rafael C. Sobrinho, r & 617 & 61 & 99 \\
\hline Raul Ribeiro da Costa, r & 399 & 48 & 120 \\
\hline Santa Filomena, $r$ & 231 & 43 & 186 \\
\hline Santina Martello Matarazzo, r & 435 & 45 & 103 \\
\hline Silvino Ortiz, r & 230 & 11 & 48 \\
\hline$x, r$ & 68 & 4 & 59 \\
\hline
\end{tabular}

Onde: av- avenida; r- rua; vl- viela 
Na Figura 1 indica-se a distribuição de todas as espécies observadas nas vias públicas da Estância de Águas de São Pedro relacionadas com classes de diâmetro à altura do peito (DAP). Cada uma das espécies está representada com a quantidade de indivíduos cadastrados. Observa-se uma curva com tendência de queda conforme se aumenta a classe de DAP. Apenas a classe de DAP maior que 0,61m mostra-se alta e esse fato se deve à sua pouca distribuição, ou seja, se houvesse continuidade na distribuição da classe de DAP maior que $0,61 \mathrm{~m}$ de 0,05 em $0,5 \mathrm{~m}$, a tendência da curva em queda se manteria.

A Figura 1 relaciona a grande diversidade de espécies e a maior quantidade de indivíduos com as menores classes de DAP. Os dados revelam que há um número alto de plantios recentes, com uma grande diversidade de espécies na Estância de Águas de São Pedro. Em levantamento realizado na Estância de Campos de Jordão observa-se poucos plantios recentes (Andrade, 2002).

Pode-se afirmar que as menores classes de DAP são realmente mudas, pois os arbustos não recebem poda de condução e tiveram o DAP medido na base do arbusto, ou seja, o arbusto apresentando-se extremamente ramificado, conforme sua idade.

Observa-se ainda que conforme a classe de DAP aumenta, diminui a diversidade de espécies, ou seja, certas espécies se estabelecem e se estabilizam nessa arborização.

Nota-se também uma mudança na distribuição das espécies a serem plantadas, na medida em que ocorre um aumento de plantio de espécies arbustivas. A manter-se essa prática, é bem provável que os novos plantios não sejam suficientes para manter a freqüência das espécies de maior DAP, o que pode se traduzir, futuramente, em menor conforto ambiental ao município. Deve-se então, atentar para essa tendência e tomar alguns cuidados, como seguir a recomendação de plantio de espécies arbóreas com indicação para vias públicas. 


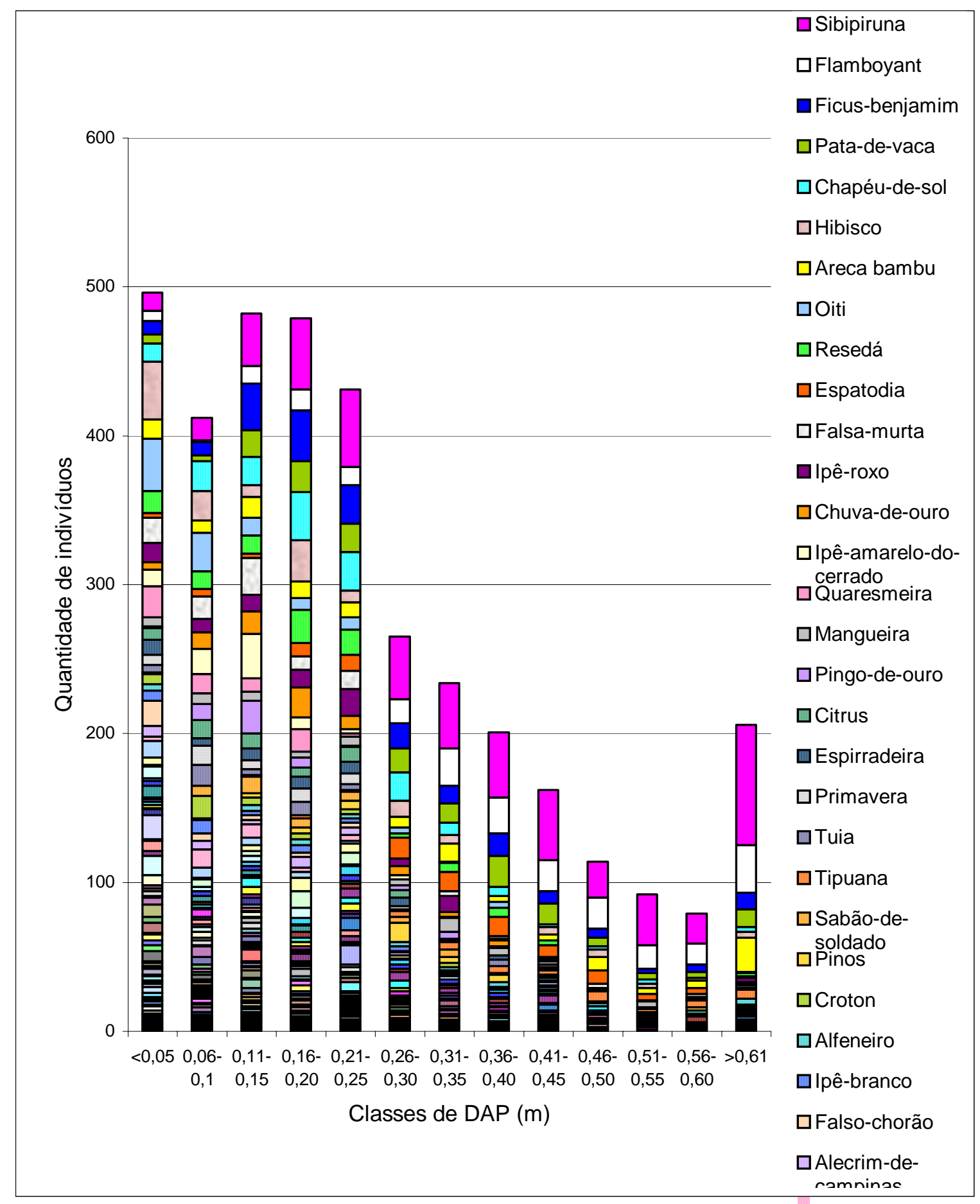

Figura 1 - Distribuição das principais espécies segundo classes de diâmetro à altura do peito (DAP) e quantidade de indíviduos, em ordem de freqüência na arborização viária da Estância de Águas de São Pedro-SP 
A Tabela 5 complementa o raciocínio da Figura 1, em relação à tendência de plantio de espécies arbustivas; observa-se a relação dos plantios recentes, referentes à distribuição dos indivíduos com altura inferior a um metro. Há a predominância de pingo-de-ouro com freqüência de $18,06 \%$, seguido de hibisco com $14,58 \%$ e oiti com $4,17 \%$.

Na Tabela 6, encontram-se a distribuição dos indivíduos com altura inferior a dois metros, com predominância do hibisco com 13,46\%, seguido de falsa-murta com 6,52\%, areca-bambu com 5,67\%, pingo-de-ouro com 5,67\%, ficus-benjamim com $4,96 \%$ e oiti $\operatorname{com} 4,27 \%$.

$\mathrm{Na}$ Tabela 7, pode ser observada a distribuição das espécies acima de dois metros, sendo as espécies de maior predominância a sibipiruna com 16,47\%, seguida de flamboyant com 7,16\%, ficus-benjamim com 5,13\%, pata-de-vaca com 5,09\%, chapéude-sol com 4,92.

Tabela 5. Distribuição das espécies de maior freqüência na arborização viária da Estância Turística de Águas de São Pedro-SP com altura inferior a 1 metro

\begin{tabular}{lc}
\hline Nome comum & Freqüência (\%) \\
\hline Pingo-de-ouro & 18,06 \\
Hibisco & 14,58 \\
Oiti & 4,17 \\
Pitangueira & 3,47 \\
Palmeira-leque & 3,47 \\
Azaléia & 2,78 \\
Falsa-murta & 2,78 \\
Outras & 50,69 \\
\hline
\end{tabular}


Tabela 6. Distribuição das espécies de maior freqüência na arborização viária da Estância Turística de Águas de São Pedro-SP com altura inferior a 2 metros

\begin{tabular}{lc}
\hline Nome comum & Freqüência (\%) \\
\hline Hibisco & 13,46 \\
Falsa-murta & 6,52 \\
Pingo-de-ouro & 5,67 \\
Areca-bambu & 5,67 \\
Ficus-benjamim & 4,96 \\
Oiti & 4,27 \\
Quaresmeira & 3,40 \\
Tuia & 2,97 \\
Outras & 53,08 \\
\hline
\end{tabular}

Tabela 7. Distribuição das espécies de maior freqüência na arborização viária da Estância Turística de Águas de São Pedro-SP com altura superior a 2 metros

\begin{tabular}{lc}
\hline Nome comum & Freqüência (\%) \\
\hline Sibipiruna & 16,47 \\
Flamboyant & 7,16 \\
Ficus-benjamim & 5,13 \\
Pata-de-vaca & 5,09 \\
Chapéu-de-sol & 4,92 \\
Areca-bambu & 2,85 \\
Reseda & 2,78 \\
Ipê-roxo & 2,61 \\
Outras & 52,99 \\
\hline
\end{tabular}




\subsection{Situação geral}

Em relação à condição geral dos indivíduos cadastrados, verificou-se que 1,08\% apresentaram-se mortos; 3,85\% em estado péssimo; $15,35 \%$ em estado regular; $58,68 \%$ em estado bom e $20,50 \%$ em estado ótimo. A maior porcentagem de indivíduos em ótimo estado coube ao ficus-benjamin, com 10,83\%, seguido da sibipiruna com $8,20 \%$ (Tabela 8$)$.

Notou-se que em 1,09\% dos indivíduos, havia a presença de hemiparasitas (erva-de-passarinho) em seus ramos. Em levantamento da arborização da cidade de Porto Alegre-RS, 8,62\% dos indivíduos apontavam-se infestados e este percentual foi considerado relativamente baixo (Oliveira, 1994).

A maioria dos indivíduos cadastrados não apresentavam problemas sanitários graves. Contudo, $0,57 \%$ dos indivíduos haviam tido ataque pesado de pragas, sendo as brocas e os cupins os maiores responsáveis por esses ataques. Na cidade de Piracicaba a sibipiruna apresentou as maiores porcentagens tanto de plantas doentes (14,97\%) como praguejadas $(25,67 \%)$, segundo o autor, devido a sua predominância sobre as demais espécies (Lima et al., 1994).

A porcentagem de indivíduos que apresentaram lesões graves foi de 1,94\% (Tabela 9)(Figura 2 - a). Essa porcentagem pode ser considerada baixa se comparada com Campos de Jordão, onde 66\% das árvores cadastradas apresentavam lesões graves (Andrade, 2002).

É interessante ressaltar que o ato de vandalismo, na arborização, é uma prática rara no município, o que pode ser atribuído ao fato de os moradores locais prezarem o espaço em que vivem e também aos turistas, que procuram a cidade justamente pelos seus aspectos ambientais. Observa-se, então, que há um movimento contrário ao vandalismo: o da conservação. Outro dado importante é o fato de que para $45,37 \%$ dos indivíduos inventariados ocorria no mínimo uma árvore plantada dentro do imóvel fronteiriço. 

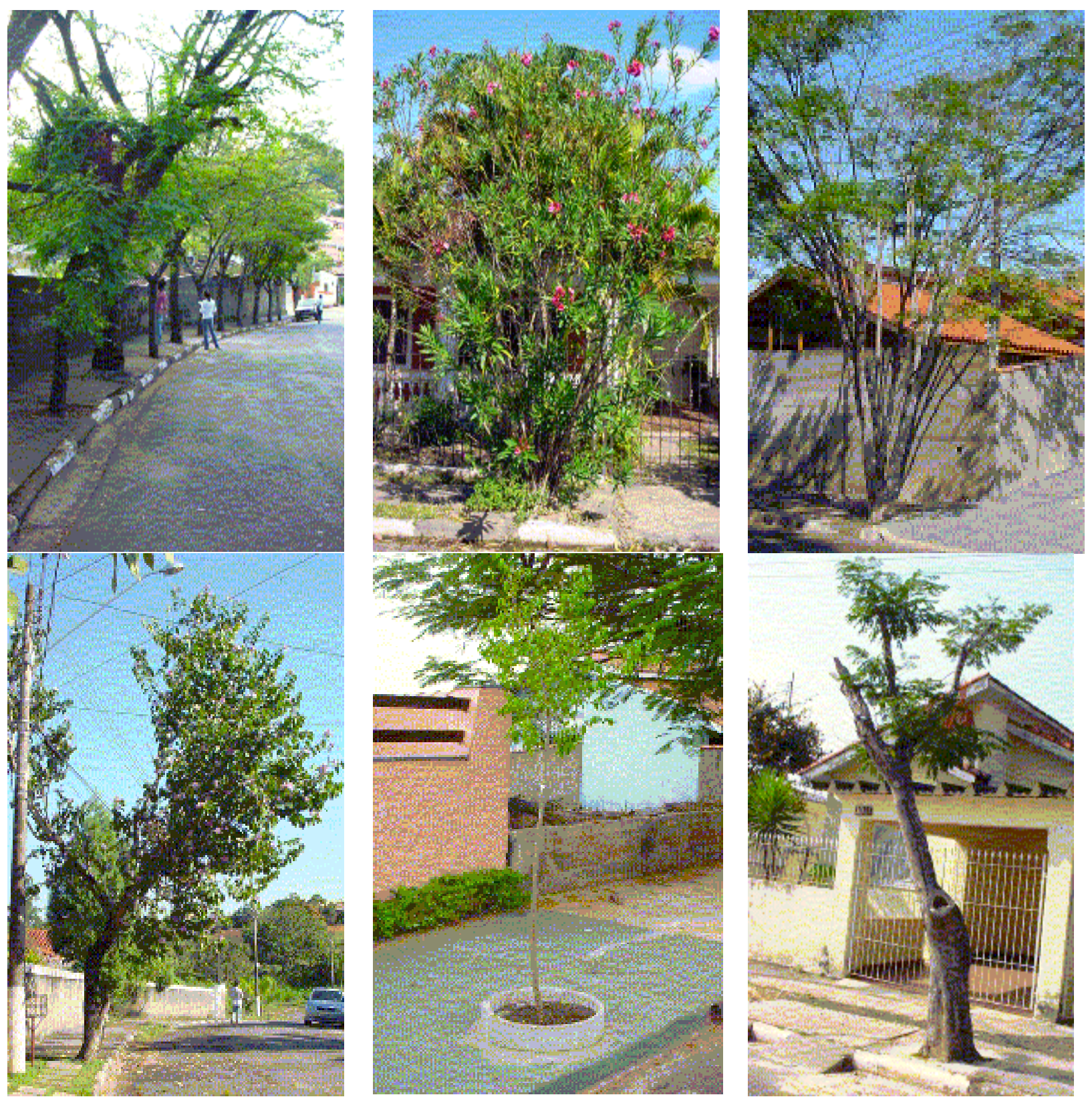

Figura 2 -Exemplos de indivíduos da arborização viária da Estância de Águas de São Pedro; a) indivíduos apresentando lesão grave; b) arbusto sem poda de condução e sem a altura mínima de bifurcação; c) árvore em contato atual com a fiação aérea; d) indivíduo desequilibrado, devido a podas por presença de fiação, poste e iluminação; e) utilização inadequada de manilha; f) indivíduo com indicação de substituição (lesão grave e ataque de pragas) 
No tocante ao equilíbrio dos indivíduos inventariados, $62,15 \%$ da arborização viária apresentou desequilíbrio no caule, na copa ou em ambos, o que indica que os plantios foram realizados com mudas de pequeno porte, com pouca ou nenhuma poda de condução. Esse quadro aponta para a possibilidade de problemas futuros. Em Jaboticabal, constatou-se que 28,39\% das árvores possuíam tal desequilíbrio (Silva Filho, 2002).

Um dado que confirma a falta de condução e o plantio de mudas pequenas na arborização viária da Estância de Águas de São Pedro é o fato de que se observou, como altura média da primeira bifurcação, a medida de 1,18m. A título de comparação, observou-se que em Manaus, a altura média encontrada foi de 1,33m, considerada bem abaixo do mínimo recomendado, que é de 1,80m (Costa \& Higuchi, 1999). Os resultados indicam que a adequação do porte das mudas a serem plantadas, e a posterior poda de condução das mesmas são requisitos essenciais para o êxito de uma arborização viária (Figura $2-b$ ).

Observou-se, para os indivíduos cadastrados a altura média de 5,10m, o diâmetro médio de copa de $4,14 \mathrm{~m}$ e o diâmetro médio do caule a altura do peito de 0,38m. Em inventário do município de Itaguaí-RJ, foram observados os seguintes dados: a altura média de 6,81m e diâmetro médio de copa de 5,32m (Malavasi et al., 1994), indicando neste caso, plantios mais antigos ou o uso de espécies de maior porte.

Com relação à situação adequada, ou seja, a harmonia entre a arborização viária e os elementos urbanos, 54,62\% da arborização viária preenchiam esse requisito, ou seja, quadro aquém do desejável. Assim, fica patente a necessidade de um melhor planejamento das espécies a serem plantadas nas vias.

Na Estância de Águas de São Pedro, observou-se que em 0,57\% dos indivíduos cadastrados apresentavam-se com mais de um exemplar numa mesma cova, prática que deve ser evitada. 
Tabela 8. Distribuição das espécies de maior freqüência na arborização viária da Estância Turística de Águas de São Pedro-SP em ótimas condições gerais

\begin{tabular}{lc}
\hline Nome comum & Freqüência (\%) \\
\hline Ficus-benjamim & 10,83 \\
Sibipiruna & 8,20 \\
Hibisco & 5,68 \\
Oiti & 5,02 \\
Ipê-amarelo-do-cerrado & 4,23 \\
Areca-bambu & 4,10 \\
Flamboyant & 3,83 \\
Tuia & 3,70 \\
Falsa-murta & 3,57 \\
Chapéu-de-sol & 3,04 \\
Ipê-roxo & 3,04 \\
Outras & 44,76 \\
\hline
\end{tabular}

Tabela 9. Distribuição das espécies na arborização viária da Estância Turística de Águas de São Pedro-SP com lesão grave

\begin{tabular}{lc}
\hline Nome Comum & Freqüência (\%) \\
\hline Sibipiruna & 57,75 \\
Primavera & 9,86 \\
Flamboyant & 8,45 \\
Tipuana & 4,23 \\
Quaresmeira & 2,82 \\
Espatódea & 2,82 \\
Malvavisco & 1,41 \\
Alecrim-de-campinas & 1,41 \\
Amoreira & 1,41 \\
Aroeira-pimenteira & 1,41 \\
Abacateiro & 1,41 \\
Lanterna-japonesa & 1,41 \\
Pata-de-vaca & 1,41 \\
Pau-brasil & 1,41 \\
Siriguela & 1,41 \\
Ipê-roxo & 1,41 \\
\hline
\end{tabular}




\subsection{Arborização e elementos urbanos}

Observou-se na Estância de Águas de São Pedro, que 36,56\% da arborização viária apresenta possibilidade de contato com a fiação elétrica ou telefônica, ocorrendo predomínio da sibipiruna com 10,04\% (Tabela 10). Em contato com a fiação, houve $15,56 \%$ da arborização viária, predominando também a sibipiruna com $28,60 \%$ (Tabela 11)(Figura 2 -c). Em Jaboticabal, observou-se que $6,83 \%$ da arborização viária está em contato atual com a fiação (Silva Filho, 2002); em Campos de Jordão observou-se 23,3\% (Andrade, 2002) e na cidade de Piracicaba, as espécies mais freqüentes apresentavam a maioria dos exemplares sob a fiação aérea, com predomínio da tipuana, com 84,04\% (Lima et al., 1994).

Na Estância de Águas de São Pedro, encontrou-se, portanto, 52,12\% dos indivíduos da arborização viária sob fiação, em contato atual ou potencial, indicando a ocorrência de podas, seus possíveis efeitos deletérios ao vigor e estrutura do indivíduo, além da poluição visual gerada (Figura $2-\mathrm{d}$ ). Sugerindo que se proceda a iniciativa de soluções alternativas para tais fatos.

No país, essas iniciativas são ainda tímidas e indicam soluções alternativas para os conflitos dos equipamentos urbanos e a arborização, como: isolamento ou proteção da fiação elétrica, modificações na disposição dos fios e dos postes, modificações nos sistemas de iluminação pública, troca da fiação aérea pela subterrânea. Essas são, enfim, medidas que fazem parte de um planejamento de instalação de novos equipamentos urbanos de forma a permitir a existência da arborização (Cerezo \& Martins, 1994). A rede compacta protegida, por exemplo, poderia ser utilizada, com a finalidade de se reduzir em mais de $80 \%$ a necessidade de poda na arborização urbana de médio e grande portes, ainda com a vantagem de ter seu custo de implantação relativamente baixo; essa técnica foi adotada pelo município de Maringá com sucesso (Farhat \& Maróstica, 1994). $\mathrm{O}$ uso de redes elétricas mais específicas reduz as interrupções e inteferências com árvores, reduz a poluição visual provocada pelas redes, aumenta a segurança e reduz perdas de energia (Kuguimiya, 1994). 
Em relação ao posteamento, observou-se que em 3,87\% da arborização viária havia contato atual e que em $6,67 \%$, ocorria essa possibilidade de contato.

Quanto à iluminação pública, constatou-se que 1,30\% da arborização viária obstruía a iluminação e que em $2,94 \%$, ocorria a possibilidade dessa obstrução. A cidade de Maringá-PR teve esse problema solucionado com o rebaixamento da iluminação, uma alternativa bastante viável, segundo Farhat \& Maróstica (1994).

Os problemas relacionados com a sinalização do tráfego de veículos não foram expressivos, pois se observou que apenas $0,17 \%$ da arborização viária estaria em conflito com a sinalização e que em $0,13 \%$, ocorria essa possibilidade.

Constatou-se que em $82,40 \%$ da arborização viária havia espaço disponível para o seu desenvolvimento. Em Manaus $76 \%$ da arborização apresentou tal característica (Costa \& Higuchi, 1999).

Tabela 10. Distribuição das espécies de maior freqüência na arborização viária da Estância Turística de Águas de São Pedro-SP, com contato potencial de alcance da fiação aérea

\begin{tabular}{lc}
\hline Nome comum & Freqüência (\%) \\
\hline Sibipiruna & 10,04 \\
Chapéu-de-sol & 5,42 \\
Ficus-benjamim & 5,42 \\
Pata-de-vaca & 5,27 \\
Hibisco & 4,25 \\
Areca-bambu & 4,25 \\
Flamboyant & 3,81 \\
Oiti & 3,52 \\
Outras & 58,02 \\
\hline
\end{tabular}


Tabela 11. Distribuição das espécies de maior freqüência na arborização viária da Estância Turística de Águas de São Pedro-SP, com contato atual com a fiação aérea

\begin{tabular}{lc}
\hline Nome comum & Freqüência (\%) \\
\hline Sibipiruna & 28,60 \\
Flamboyant & 10,20 \\
Pata-de-vaca & 8,74 \\
Ficus-benjamim & 7,10 \\
Chapéu-de-sol & 4,37 \\
Espatódea & 2,37 \\
Outras & 38,62 \\
\hline
\end{tabular}

\subsubsection{Calçamentos e raízes}

Constatou-se que a largura média das calçadas da Estância de Águas de São Pedro foi de $2,35 \mathrm{~m}$ e que $14,56 \%$ dos indivíduos cadastrados causam danos ao calçamento. Dentre esses, destacam-se a sibipiruna com $29,85 \%$ e o flamboyant com 19,40\% (Tabela 12). Em Jaboticabal, 22,50\% das árvores cadastradas estavam danificando o calçamento (Silva Filho, 2002); em Campos de Jordão 46,8\% das árvores cadastradas prejudicavam o calçamento (Andrade, 2002); em Piracicaba as espécies nas quais se evidenciaram problemas causando danos a calçada foram as tipuanas com $85,11 \%$, as sibipirunas com $80,41 \%$, os flamboyants com $78,72 \%$ e os chapéus-de-sol com 60,27\% (Lima et al., 1994); em Porto Alegre, as espécies mais freqüentes da arborização de vias também apresentavam elevado percentual de danos a passeios e pavimentações. Nota-se, a partir desses dados, que se mostra fundamental promover estudos de composição, estrutura e manejo do solo urbano, pois são fatores que influenciam expressivamente o comportamento do sistema radicular (Roso, 1994).

Na Estância de Águas de São Pedro, também se observou que 9 indivíduos oito indivíduos da espécie Tipuana tipu (tipuana) e um da espécie Spathodea nilotica (espatódea) - apresentavam suas raízes aflorando no leito carroçável, o que representa $0,25 \%$ da população. 
Dos indivíduos cadastrados, $1,41 \%$ possuíam manilha aparente em seu local de plantio (Figura 2 - e); o que representa uma pequena quantidade se comparada à arborização de Jaboticabal, com 8,01\% (Silva Filho, 2002). Não obstante poucos indivíduos apresentarem manilha, esse fato merece atenção e torna-se mesmo preocupante, principalmente se o seu uso for incentivado e recomendado pelos órgãos públicos. Na medida em que acarreta a diminuição da estabilidade das raízes, pela falta de espaço e pela baixa capacidade de volume de substrato, o uso de manilha oferece risco à segurança das vias públicas.

Constatou-se ainda que $1,99 \%$ dos indivíduos da arborização viária apresentavam o colo da planta circundado por pavimento.

Tabela 12. Distribuição das espécies de maior freqüência na arborização viária da Estância Turística de Águas de São Pedro-SP, que apresentam afloramento de raízes na calçada

\begin{tabular}{lc}
\hline Nome comum & Freqüência (\%) \\
\hline Sibipiruna & 29,85 \\
Flamboyant & 19,40 \\
Chapéu-de-sol & 5,78 \\
Espatódea & 5,78 \\
Pata-de-vaca & 5,60 \\
Tipuana & 4,29 \\
Ficus-benjamina & 3,92 \\
Outras & 25,38 \\
\hline
\end{tabular}

\section{4 Índices de diversidade}

Ao serem utilizados índices que usam apenas o número total de espécies e o somatório das abundâncias de indivíduos em uma comunidade, os chamados índices de riqueza ou variedade (Coelho, 2000); tem-se, segundo cálculos de Odum, um índice para a arborização viária da Estância de Águas de São Pedro de 19,50. Na cidade de Jaboticabal, esse índice é de 12,98 (Silva Filho et al., 2002). 
Quanto aos índices de diversidade que partem do pressuposto de que as espécies têm abundâncias diferentes, como o caso da arborização viária encontrada, temse o índice de Shannon-Wiener (Coelho, 2000) igual a 3,90 para a arborização viária da Estância de Águas de São Pedro. Para os bairros da Orla de Santos, obteve-se um índice de 2,63 (Menegueti 2003).

Observa-se que esses dois índices da arborização viária da Estância de Águas de São Pedro, comparativamente aos encontrados em outras cidades, apresentam-se superiores, o que revela uma diversidade mais adequada.

Sob o ponto de vista de composição paisagística, essa maior riqueza de diversidade não garante as funções estéticas esperadas, o que poderia ser conseguido com um melhor agrupamento dos indivíduos esparsos dessa arborização. Pois se observou que apenas $49,61 \%$ dos indivíduos cadastrados, tiveram participação positiva na paisagem, ou seja, com um ou mais indivíduos da mesma espécie próximos.

A interferência da população na arborização viária também não contribui para a composição paisagística do local. Dessa forma, não obstante haver contribuição dessa interferência para o incremento da diversidade e do número de indivíduos, observa-se falha na função paisagística. Na cidade de Brasília, o mesmo quadro pode ser verificado, o que resulta na descaracterização do seu projeto inicial de arborização de quadras (Rodrigues, 1994). Fica então patente à necessidade de o setor público interferir, seja orientando a população, seja regulamentando essa prática.

\subsection{Indicadores de qualidade}

$\mathrm{Na}$ época do levantamento de campo, em julho de 2003, encontrou-se, na

Estância de Águas de São Pedro, apenas 21 indivíduos com a presença de ninhos de passarinhos, o que equivale a $0,54 \%$ da arborização viária. A maior parte desses ninhos localizava-se nas espécies sibipiruna, calabura, flamboyant e sabão-de-soldado (Tabela 13). Em Jaboticabal, durante os meses de janeiro à dezembro de 2001, foram encontrados ninhos em 2,53\% da arborização viária, também prevalecendo a espécie 
sibipiruna. Esses dados mostram a importância dessa espécie para a avifauna e, por extensão, como a sibipiruna funciona como indicadora de qualidade de vida nas cidades (Silva Filho, 2002).

Quanto aos líquens, encontrou-se na arborização viária, em 14,23\% dos indivíduos. Sendo a sibipiruna, a espécie em que mais ocorreram, com 35\%, (Tabela 14). Em Jaboticabal, foram encontrados em 14,44\% (Silva Filho, 2002).

Tabela 13. Distribuição das espécies com presença de ninhos na arborização viária da Estância Turística de Águas de São Pedro-SP

\begin{tabular}{lc}
\hline Nome Comum & Freqüência (\%) \\
\hline Sibipiruna & 33.33 \\
Sabão-de-soldado & 9.52 \\
Flamboyant & 9.52 \\
Calabura & 9.52 \\
Tipuana & 4.76 \\
Pitangueira & 4.76 \\
Oiti & 4.76 \\
Jequitibá-rosa & 4.76 \\
Ipê-roxo & 4.76 \\
Ipê-mirim & 4.76 \\
Canelinha & 4.76 \\
Alecrim-de-campinas & 4.76 \\
\hline
\end{tabular}


Tabela 14. Distribuição das espécies de maior freqüência com presença de líquens na arborização viária da Estância Turística de Águas de São Pedro-SP

\begin{tabular}{lc}
\hline Nome Comum & Freqüência (\%) \\
\hline Sibipiruna & 35,00 \\
Flamboyant & 11,35 \\
Chapéu-de-sol & 6,73 \\
Pata-de-vaca & 6,15 \\
Espatódea & 5,00 \\
Tipuana & 4,04 \\
Sabão-de-soldado & 3,08 \\
Ipê-roxo & 2,88 \\
Citrus & 2,50 \\
Ipê-amarelo-do-cerrado & 2,31 \\
Alecrim-de-campinas & 1,73 \\
Outras & 19,23 \\
\hline
\end{tabular}

\subsection{Ações executadas e ações recomendadas}

Na Estância de Águas de São Pedro constatou-se, em 3,61\% da arborização viária a presença de podas pesadas, ou seja, de indivíduos mutilados. Não se observou outras ações diferenciadas, além das próprias podas, que, aliás, necessitam de adequação e aprimoramento.

Obteve-se indicação de substituição de 2,65\% da arborização viária total, com destaque para as árvores mortas (34,02\%), a sibipiruna (18,56\%), a primavera e o pingo de ouro (ambos com 5,15\%) (Tabela 15). Os indivíduos arbóreos que tiveram indicação de substituição apresentavam-se em fase final de declínio, alguns com ataque severo de doenças e pragas (Figura 2 - f). Note-se que os indivíduos arbustivos tiveram recomendação de substituição devido ao pouco benefício ambiental proporcionado e por se situarem em locais com possibilidade de substituição.

$\mathrm{Na}$ arborização viária da Estância de Águas de São Pedro encontrou-se um total de 312 covas vazias. Destas, apenas 202 tiveram indicação de plantio, o que se justifica pela inadequação da localização das covas, como em frente a garagens, postes e esquinas. 
Tabela 15. Distribuição das espécies com recomendação de substituição na arborização viária da Estância Turística de Águas de São Pedro-SP

\begin{tabular}{lc}
\hline Nome Comum & Freqüência (\%) \\
\hline Mortas & 34,02 \\
Sibipiruna & 18,56 \\
Primavera & 5,15 \\
Pingo-de-ouro & 5,15 \\
Azaléia & 4,12 \\
Flamboyant & 4,12 \\
Jacarandá-mimoso & 3,09 \\
Mangueira & 3,09 \\
Tipuana & 3,09 \\
Hibisco & 2,06 \\
Lanterna-japonesa & 2,06 \\
Outras & 15,49 \\
\hline
\end{tabular}

\subsection{Outras informações relevantes}

Na arborização viária da Estância Turística de Águas de São Pedro constatou-se 61,33\% de espécies exóticas e 38,67\% de espécies nativas (Tabela 16). Em Brasília, os novos plantios têm priorizado as espécies nativas da região (Rodrigues et al., 1994), devendo-se seguir esse exemplo.

Observou-se também, que 70,85\% das espécies cadastradas são arbóreas, 19,90\% são arbustivas, 6,05\% são palmeiras e 3,20\% são coníferas (Tabela 16). Em Brasília, observou-se $63,55 \%$ das espécies de porte arbóreo, 28,03\% de porte arbustivo e 7,47\% de palmáceas (Rodrigues et al., 1994); em Recife observa-se 48\% de árvores de grande porte (Freire et al., 1994).

As datas de maior visitação na Estância Turística de Águas de São Pedro são os feriados prolongados e as férias, destacando-se também o Reveillon e o Carnaval, além de visitas sem datas especiais para a Casa de Santiago, o mini-horto municipal, ponto de chegada do "Caminho do Sol"; alguns eventos também atraem um grande público para a cidade que nem sempre coincidem com os feriados, no Centro de Exposições e Eventos relacionados ao turismo de negócios. Como se observa, tem-se a presença de turistas no 
decorrer de todo o ano, recomenda-se então, que as épocas de florescimento dos indivíduos arbóreos da arborização viária sejam distribuídas em todo o seu decorrer.

Nota-se que os indivíduos com a época de florescimento marcada em negrito (Tabela 16), são espécies com indicação de plantio para vias públicas, com atrativos que se destacam pelo florescimento, aroma e/ou fruto. Estas perfazem 44,75\% da arborização viária da Estância de Águas de São Pedro; que pode vir a ser incrementada com o plantio dessas espécies pouco representadas nesse inventário. Observa-se também, que dessas espécies, $62,60 \%$ expõem sua característica atrativa no inverno/primavera, $34,67 \%$ na primavera/verão; $2,52 \%$ no outono/inverno; $0,25 \%$ no verão /outono. 
Tabela 16. Relação das espécies na arborização viária da Estância Turística de Águas de São Pedro-SP, com sua procedência, hábito de crescimento e época de florescimento

\begin{tabular}{|c|c|c|c|}
\hline Nome científico & Procedência & $\begin{array}{c}\text { Hábito } \\
\text { crescim. }\end{array}$ & $\begin{array}{l}\text { Época } \\
\text { floresc. }\end{array}$ \\
\hline Caesalpinia peltophoroides Benth. & nativa & árvore & $\mathbf{i} / \mathbf{p}$ \\
\hline Delonix regia (Bojer ex Hook.) Raf. & exótica & árvore & $\mathrm{p} / \mathrm{v}$ \\
\hline Ficus benjamina L. & exótica & árvore & $*$ \\
\hline Bauhinia variegata L. & exótica & árvore & $\mathbf{i} / \mathbf{p}$ \\
\hline Terminalia catappa L. & exótica & árvore & $\mathrm{p}$ \\
\hline Hibiscus rosa-sinensis L. & exótica & arbusto & ano todo \\
\hline Dypsis lutescens H. Wendl. & exótica & palmeira & $\mathrm{p} / \mathrm{v}$ \\
\hline Licania tomentosa (Benth.) Fritsch. & nativa & árvore & $\mathrm{i} / \mathrm{p}$ \\
\hline Lagerstroemia indica L. & exótica & arbusto & $\mathbf{p} / \mathbf{v}$ \\
\hline Spathodea nilotica Seem & exótica & árvore & $\mathbf{p} / \mathbf{v} / \mathbf{0}$ \\
\hline Murraya paniculata (L.) Jacq. & exótica & arbusto & ano todo \\
\hline Tabebuia sp & nativa & árvore & - \\
\hline Cassia fistula L. & exótica & árvore & $\mathbf{p}$ \\
\hline Tabebuia chrysotricha (Mart. ex DC.) Stand. & nativa & árvore & $\mathbf{i} / \mathbf{p}$ \\
\hline Tibouchina granulosa (Desc.) Cogn & nativa & árvore & $\mathbf{i} / \mathbf{v}$ \\
\hline Mangifera indica L. & exótica & árvore & $\mathrm{i} / \mathrm{p}$ \\
\hline Duranta repens L. & nativa & arbusto & $\mathrm{p} / \mathrm{v}$ \\
\hline Citrus sp & exótica & árvore & $*$ \\
\hline Nerium oleander L. & exótica & arbusto & $\mathbf{p} / \mathbf{v} / \mathbf{o}$ \\
\hline Bougainvillea spectabilis Willd & nativa & arbusto & $\mathrm{o} / \mathrm{i}$ \\
\hline Thuja occidentalis L. & exótica & conífera & $*$ \\
\hline Pinus elliotti Engel. & exótica & conífera & * \\
\hline Sapindus saponaria L. & nativa & árvore & $\mathrm{o} / \mathrm{i}$ \\
\hline Tipuana tipu (Benth.) Kuntze & exótica & árvore & $\mathrm{p} / \mathrm{v}$ \\
\hline Codiaeum variegatum Blume & exótica & arbusto & $*$ \\
\hline Ligustrum lucidum W. T. Aiton & exótica & árvore & $\mathrm{p} / \mathrm{v}$ \\
\hline Holocalyx balansae Mich. & nativa & árvore & $\mathrm{i} / \mathrm{p}$ \\
\hline Schinus molle L. & nativa & árvore & $\mathrm{p}$ \\
\hline Tabebuia roseo-alba (Ridl.) Sandw. & nativa & árvore & $\mathbf{i} / \mathbf{p}$ \\
\hline Psidium guajava L. & nativa & árvore & $\mathrm{p}$ \\
\hline Eugenia uniflora L. & nativa & arbusto & $\mathrm{i} / \mathrm{p}$ \\
\hline Michelia champaca L. & exótica & árvore & $\mathrm{p}$ \\
\hline Cocos nucifera L. & nativa & palmeira & $\mathrm{V}$ \\
\hline Caesalpinia echinata Lam. & nativa & árvore & $\mathbf{i} / \mathbf{p}$ \\
\hline Schinus terebinthifolius Raddi & nativa & árvore & $\mathrm{V}$ \\
\hline Tabebuia pentaphylla Hemsl. & exótica & árvore & $\mathbf{i} / \mathbf{p}$ \\
\hline Bauhinia variegata L. var. candida & exótica & árvore & $\mathbf{i} / \mathbf{p}$ \\
\hline Grevillea robusta A. Cunn. Ex. R. Br. & exótica & árvore & $\mathrm{i} / \mathrm{p} / \mathrm{v}$ \\
\hline Jacaranda mimosaefolia D. Don & nativa & árvore & $\mathbf{i} / \mathbf{p}$ \\
\hline Ficus benjamina L. var. variegata & exótica & árvore & $*$ \\
\hline Morus nigra L. & exótica & árvore & $*$ \\
\hline Myrciaria trunciflora Berg. & nativa & árvore & $\mathrm{i} / \mathrm{p}$ \\
\hline Plumeria rubra L. & exótica & árvore & $\mathrm{i} / \mathrm{p}$ \\
\hline Koelreuteria elegans (Seem.) A.C.Sm. & exótica & árvore & $\mathbf{0}$ \\
\hline
\end{tabular}


Tabela 16. Relação das espécies na arborização viária da Estância Turística de Águas de São Pedro-SP, com sua procedência, hábito de crescimento e época de florescimento

\begin{tabular}{|c|c|c|c|}
\hline Nome científico & Procedência & $\begin{array}{c}\text { Hábito } \\
\text { cresc. }\end{array}$ & $\begin{array}{r}\text { Época } \\
\text { floresc. }\end{array}$ \\
\hline Cordyline terminalis Kunth & exótica & arbusto & - \\
\hline Stenolobium stans (L.) Seem. & exótica & arbusto & $\mathrm{p} / \mathrm{v}$ \\
\hline Roystonea regia (H. B. K.) O. F. Cook & exótica & palmeira & $\mathrm{p}$ \\
\hline Lafoensia glyptocarpa Koehne & nativa & árvore & $\mathrm{i}$ \\
\hline Mussaenda erythrophylla Schum. \& Thonning & exótica & arbusto & $\mathrm{p} / \mathrm{v}$ \\
\hline Persea americana L. & exótica & árvore & - \\
\hline Thevetia peruviana K. Schum. & exótica & arbusto & \\
\hline Syagrus romanzoffiana (Cham.) Glassm. & nativa & palmeira & $\mathrm{p} / \mathrm{v}$ \\
\hline Melia azedarach L. & exótica & árvore & p \\
\hline Malpighia punicifolia L. & nativa & arbusto & $\mathrm{i}$ \\
\hline Caesalpinia ferrea Mart. ex Tul. var. leiostachya Benth. & nativa & árvore & $\mathrm{v} / \mathrm{o}$ \\
\hline Cupressus sempervirens L. & exótica & conífera & - \\
\hline Eriobotrya japonica (Thunb.) Lind. & exótica & árvore & $\mathrm{v} / \mathrm{o}$ \\
\hline Caesalpinia pulcherrima Sw. & exótica & arbusto & $\mathrm{p} / \mathrm{v}$ \\
\hline Roystonea oleracea (N. J. Jacquin) O. F. Cook & exótica & palmeira & $\mathrm{p} / \mathrm{v} / \mathrm{o}$ \\
\hline Livistonia chinensis (N. J. Jacquin) R. Brown ex Mart & exótica & palmeira & - \\
\hline Euphorbia leucocephala Lotsy & exótica & arbusto & $\mathrm{i}$ \\
\hline Muntingia calabura L. & exótica & árvore & - \\
\hline Grevillea banksii R. Br. & exótica & arbusto & $\mathbf{0} / \mathbf{i} / \mathbf{p}$ \\
\hline Leucena leucocephala (Lam.) R. de Wit & exótica & árvore & $\mathrm{p}$ \\
\hline Brunfelsia uniflora D. Don. & nativa & arbusto & $\mathrm{p} / \mathrm{v}$ \\
\hline Bauhinia blakeana Dunn & exótica & árvore & $\mathbf{0} / \mathbf{i}$ \\
\hline Thuja sp & exótica & conífera & - \\
\hline Dombeya wallichii (Lindl.) K. Schum. & exótica & árvore & $\mathbf{p} / \mathbf{v}$ \\
\hline Nectandra megapotamica (Spreng.) Mez & nativa & árvore & $\mathrm{i}$ \\
\hline Chorisia speciosa St. Hil. & nativa & árvore & $\mathrm{v} / \mathrm{o}$ \\
\hline Koelreuteria paniculata (Seem.) A.C.Sm. & exótica & árvore & \\
\hline Juniperus chinensis L. & exótica & conífera & - \\
\hline Veitchia sp & exótica & palmeira & $\mathrm{p} / \mathrm{v}$ \\
\hline Ficus microcarpa L.f. & exótica & árvore & - \\
\hline Syzygium cuminii (L.) Skeels & exótica & árvore & $\mathrm{p}$ \\
\hline Pachira aquatica Aubl. & nativa & árvore & $\mathrm{p}$ \\
\hline Aspidosperma polyneuron M. Arg. & nativa & árvore & $\mathrm{p} / \mathrm{v}$ \\
\hline Tibouchina semidecandra (DC.) Cogn & nativa & arbusto & $\mathbf{i} / \mathbf{p}$ \\
\hline Punica granatum L. & exótica & arbusto & $\mathrm{p}$ \\
\hline Araucaria columnaris (Forst.) Hook. & exótica & conífera & - \\
\hline Rhododendron simsii Planch. & exótica & arbusto & $\mathrm{o} / \mathrm{i}$ \\
\hline Elaeocarpus serratus L. & exótica & árvore & - \\
\hline Schefflera arboricola (Hayata) Merr. & exótica & arbusto & $\mathrm{p} / \mathrm{v}$ \\
\hline Calliandra brevipes Benth. & nativa & arbusto & $\mathrm{p} / \mathrm{v}$ \\
\hline Ixora coccinea $\mathrm{L}$. & exótica & arbusto & $\mathrm{p} / \mathrm{v}$ \\
\hline Carica papaya L. & nativa & árvore & - \\
\hline Tamarindus indica L. & exótica & árvore & - \\
\hline Camellia japonica L. & exótica & arbusto & $\mathrm{o} / \mathrm{i}$ \\
\hline
\end{tabular}


Tabela 16. Relação das espécies na arborização viária da Estância Turística de Águas de São Pedro-SP, com sua procedência, hábito de crescimento e época de florescimento

\begin{tabular}{|c|c|c|c|}
\hline Nome científico & Procedência & $\begin{array}{c}\text { Hábito } \\
\text { cresc. }\end{array}$ & $\begin{array}{r}\text { Época } \\
\text { floresc. }\end{array}$ \\
\hline Cestrum intermedium Sendt. & exótica & arbusto & $\mathrm{p} / \mathrm{v}$ \\
\hline Lafoensia pacari St. Hil. & nativa & árvore & $\mathrm{p} / \mathrm{v}$ \\
\hline Callistemon viminalis (Sol. ex. Gaertn.) G. Don ex Loud. & exótica & árvore & $\mathrm{i} / \mathrm{p}$ \\
\hline Eugenia sprengelli DC. & nativa & arbusto & - \\
\hline Ficus sp & exótica & árvore & - \\
\hline Casearia sylvestris Sw. & nativa & árvore & $\mathrm{p} / \mathrm{v}$ \\
\hline Calophyllum brasiliensis Camb. & nativa & árvore & - \\
\hline Platypodium elegans Vog. & nativa & árvore & $\mathrm{p}$ \\
\hline Syzygium jambos (L.) Alston & exótica & árvore & $\mathrm{p}$ \\
\hline Cariniana legalis (Mart.) Kuntze & nativa & árvore & $\mathrm{p} / \mathrm{v} / \mathrm{o}$ \\
\hline Euphorbia cotinifolia L. & exótica & arbusto & $\mathrm{v}$ \\
\hline Lophanthera lactescens Ducke & nativa & árvore & $\mathbf{0} / \mathbf{i}$ \\
\hline Caryota urens L. & exótica & palmeira & - \\
\hline Bauhinia forficata Link & nativa & arbusto & $\mathrm{p} / \mathrm{v}$ \\
\hline Spondias purpurea L. & nativa & árvore & ano todo \\
\hline Clitoria fairchildiana R. A. Howard & nativa & árvore & $\mathbf{v} / \mathbf{o}$ \\
\hline Acacia mangium Willd. & exótica & árvore & - \\
\hline Musa sp & exótica & - & - \\
\hline Melanoxylon brauna Schott & nativa & árvore & $\mathrm{v} / \mathrm{o}$ \\
\hline Peltophorum dubium (Spreng.) Taub. & nativa & árvore & $\mathrm{i} / \mathrm{p}$ \\
\hline Bombacopsis glabra (Pasq.) A. Rob. & nativa & árvore & $\mathrm{p}$ \\
\hline Salix babylonica L. & exótica & árvore & - \\
\hline Cycas circinalis L. & exótica & árvore & - \\
\hline Clerodendron sp & exótica & arbusto & - \\
\hline Cestrum nocturnum L. & exótica & arbusto & $\mathrm{p} / \mathrm{v}$ \\
\hline Melaleuca leucadendron (L.) L. & exótica & árvore & $\mathbf{p} / \mathbf{v}$ \\
\hline Breynia nivosa Small & exótica & arbusto & - \\
\hline Aleurites moluccana (L.) Willd. & exótica & árvore & $\mathrm{o}$ \\
\hline Triplaris americana L. & nativa & árvore & $\mathbf{i} / \mathbf{p} / \mathbf{v}$ \\
\hline Phoenix canariensis Hort. ex Chabaud & exótica & palmeira & - \\
\hline Annona squamosa $\mathrm{L}$. & nativa & árvore & $\mathrm{i}$ \\
\hline Senna macranthera (Collad.) Irwin et Barneby & nativa & árvore & \\
\hline Phoenix roebelenii O`Brien & exótica & palmeira & - \\
\hline Adenanthera pavonina L. & exótica & árvore & $\mathbf{0}$ \\
\hline Hovenia dulcis Thunb. & exótica & árvore & $\mathrm{V}$ \\
\hline Acacia podalyraefolia A. Cunn. Ex G. Don & exótica & árvore & $\mathbf{i}$ \\
\hline Agathis robusta (C. Moore) F. M. Bailey & exótica & conífera & - \\
\hline Allamanda laevis Markgr. & nativa & arbusto & $\mathrm{p} / \mathrm{v}$ \\
\hline Psychotria carthagenensis Jacq. & exótica & arbusto & \\
\hline Euphorbia pulcherrima Willd. Ex Klotzsch & exótica & arbusto & $\mathrm{i}$ \\
\hline Albizia lebbeck (L.) Benth. & exótica & árvore & $\mathbf{p} / \mathbf{v}$ \\
\hline Schefflera actinophylla Harms & exótica & arbusto & $\mathrm{V}$ \\
\hline Plinia glomerata (Berg.) Amsh. & nativa & arbusto & $\mathrm{o} / \mathrm{i}$ \\
\hline Myroxylon peruiferum L.f. & nativa & árvore & \\
\hline
\end{tabular}


Tabela 16. Relação das espécies na arborização viária da Estância Turística de Águas de São Pedro-SP, com sua procedência, hábito de crescimento e época de florescimento

\begin{tabular}{lccc}
\hline Nome científico & Procedência & $\begin{array}{c}\text { Hábito } \\
\text { cresc. }\end{array}$ & $\begin{array}{c}\text { Época } \\
\text { floresc. }\end{array}$ \\
\hline Coffea arabica L. & exótica & arbusto & - \\
Anacardium occidentale L. & nativa & árvore & $\mathrm{i} / \mathrm{p}$ \\
Cássia javanica L. & exótica & árvore & $\mathbf{p} / \mathbf{v}$ \\
Cedrela fissilis Vell. & nativa & árvore & $\mathrm{i} / \mathrm{p}$ \\
Prunus serrulata Lindl. & exótica & árvore & $\mathrm{i}$ \\
Ficus lyrata Warb. & exótica & árvore & - \\
Copaifera langsdorffii Desf. & nativa & árvore & $\mathrm{p} / \mathrm{v}$ \\
Cecropia hololeuca Miq. & nativa & árvore & $\mathrm{p} / \mathrm{v}$ \\
Cecropia glaziovii Snethlage & nativa & árvore & $\mathrm{i} / \mathrm{p}$ \\
Erythrina speciosa Andrews & nativa & arbusto & $\mathrm{i} / \mathrm{p}$ \\
Maytenus ilicifolia Mart. ex. Reiss. & nativa & árvore & - \\
Spiraea sp & exótica & arbusto & - \\
Ficus guaranitica Schodat & nativa & árvore & $\mathrm{p}$ \\
Garcinia sp & exótica & árvore & - \\
Yucca elephantipes Regel. & exótica & arbusto & $\mathrm{v}$ \\
Syzygium aqueum (Burm.f.) Alston & exótica & árvore & $\mathrm{v}$ \\
Syzygium malaccense (L.) Merr. \& L.M. Perry & exótica & árvore & $\mathbf{o}$ \\
Leea rubra Blume & exótica & arbusto & - \\
Macadamia integrifolia Maiden $\&$ Betch & exótica & árvore & $\mathrm{i}$ \\
Malvaviscus arboreus Cav. & exótica & arbusto & ano todo \\
Tibouchina pulchra (Cham.) & nativa & árvore & $\mathbf{p}$ \\
Swietenia sp & - & árvore & - \\
Carya illinoinensis (Wangenh.) C. Koch & exótica & árvore & $\mathrm{p}$ \\
Psidium cattleyanum Sabine & nativa & árvore & $\mathrm{i} / \mathrm{p} / \mathrm{v}$ \\
Platanus cf. orientalis (Aiton) Willd. & exótica & árvore & - \\
Rosa x grandiflora Hort & exótica & arbusto & ano todo \\
Sambucus nigra L. & exótica & arbusto & $\mathrm{p}$ \\
Lecythis pisonis Camb. & nativa & árvore & $\mathbf{p}$ \\
Cupressus macrocarpa Hartw. & exótica & conífera & - \\
Eugenia pyriformis Camb. & exótica & árvore & $\mathrm{p} / \mathrm{v}$ \\
\hline
\end{tabular}
onde: p-primavera, v-verão, o-outono, i-inverno;

espécies com época de florescimento em negrito, são indicadas para vias públicas pelo caráter ornamental; Fonte: Lorenzi, 2002a; Lorenzi, 2002b; Lorenzi \& Souza, 2001; Lorenzi et al., 2003) 


\section{CONCLUSÕES}

A arborização viária da Estância de Águas de São Pedro possui uma satisfatória distribuição de espécies, gêneros e famílias; além de possuir uma adequada diversidade de espécies e de na maioria dos casos, adequado índice de indivíduos por quilometragem de rua.

Há uma tendência de plantio de espécies arbustivas, o que pode vir a comprometer futuramente a qualidade dessa arborização. Deve-se lembrar que o fato de o município não possuir zona rural faz com que a arborização tenha relevante importância e influência no conforto ambiental da cidade e no potencial turístico.

Observou-se também que $61,33 \%$ das espécies catalogadas nas vias públicas são exóticas, portanto a valorização da flora nativa deve ser incentivada.

Segundo informações de moradores locais, a execução de serviços de implantação e manutenção da arborização viária fica a cargo das companhias elétricas ou da própria população. Apesar de a intervenção popular gerar um incremento no número de espécies, nota-se que, nessa ação, não são levadas em consideração as recomendações técnicas de implantação e manejo. Como conseqüência, as funções paisagísticas, ambientais e sociais ficam comprometidas. Ao longo das vias públicas, observam-se alguns dos problemas ocasionados por não serem atendidas as recomendações técnicas, como o plantio de mudas com alturas inferiores à recomendada, a falta de condução, a irregularidade na distribuição das espécies e as podas mal realizadas.

Há a necessidade da implementação de um plano diretor de arborização para a cidade coordenada pela Prefeitura Municipal, não somente estabelecendo regras, mas também que tenha uma função de acompanhamento e de controle mais efetivo. 
ANEXOS 
Anexo A- Planilha das características qualitativas

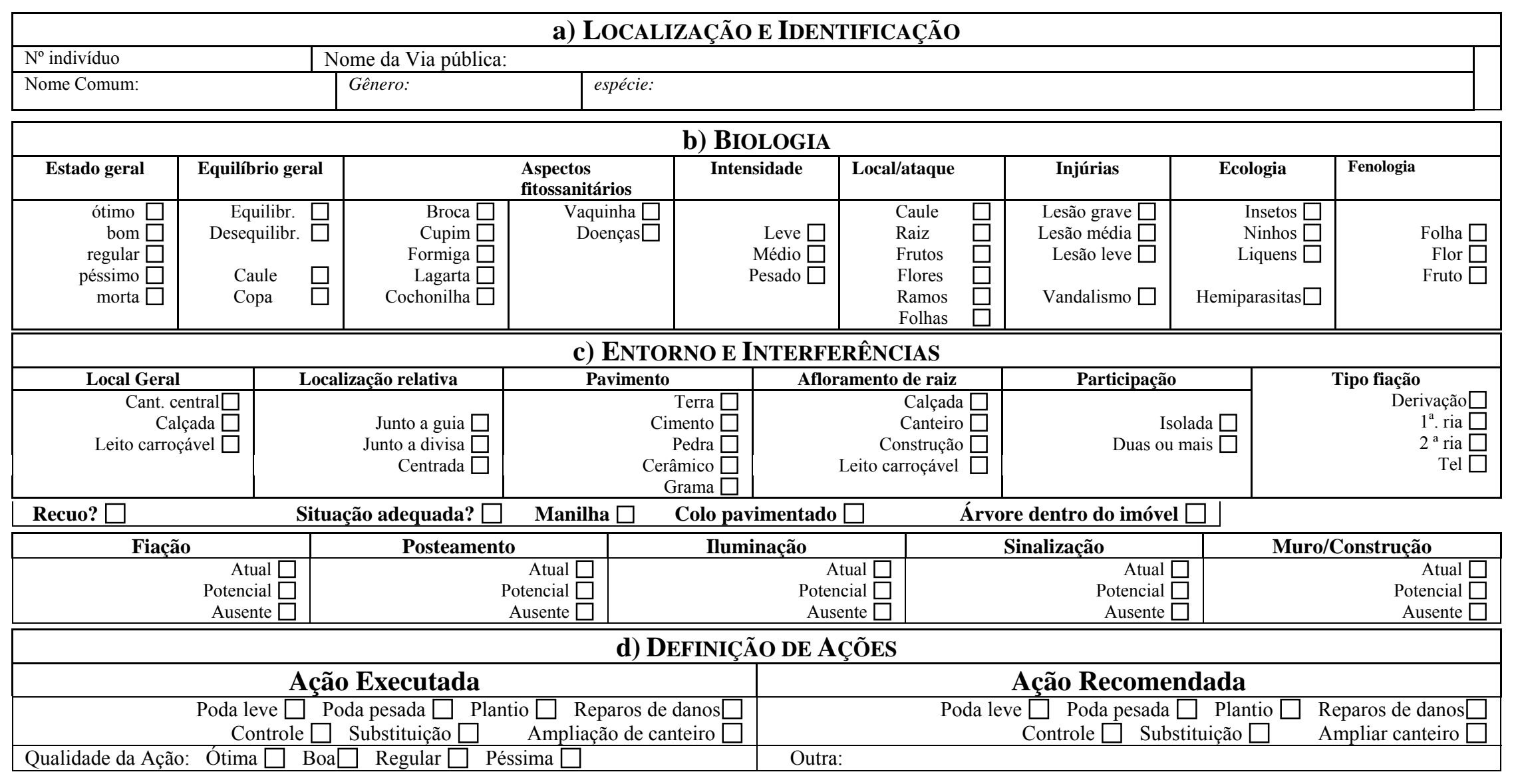


Anexo B- Planilha das características quantitativas

\begin{tabular}{|c|c|c|c|c|c|c|c|c|c|c|c|c|c|c|}
\hline \multicolumn{15}{|c|}{ E) DIMENSÕES (CM) } \\
\hline $\begin{array}{c}n^{0} \text { do } \\
\text { indivíduo }\end{array}$ & $n^{\circ}$ do imóvel & calçada & altura geral & $\begin{array}{l}\text { altura da } 1^{\circ} \\
\text { bifurcação }\end{array}$ & $\begin{array}{l}\text { diâmetro } \\
\text { da copa }\end{array}$ & CAP 1 & CAP 2 & CAP 3 & CAP 4 & CAP 5 & CAP 6 & CAP 7 & CAP 8 & CAP 9 \\
\hline & & & & & & & & & & & & & & \\
\hline & & & & & & & & & & & & & & \\
\hline & & & & & & & & & & & & & & \\
\hline & & & & & & & & & & & & & & \\
\hline & & & & & & & & & & & & & & \\
\hline & & & & & & & & & & & & & & \\
\hline & & & & & & & & & & & & & & \\
\hline & & & & & & & & & & & & & & \\
\hline & & & & & & & & & & & & & & \\
\hline & & & & & & & & & & & & & & \\
\hline & & & & & & & & & & & & & & \\
\hline & & & & & & & & & & & & & & \\
\hline & & & & & & & & & & & & & & \\
\hline & & & & & & & & & & & & & & \\
\hline & & & & & & & & & & & & & & \\
\hline & & & & & & & & & & & & & & \\
\hline & & & & & & & & & & & & & & \\
\hline & & & & & & & & & & & & & & \\
\hline & & & & & & & & & & & & & & \\
\hline & & & & & & & & & & & & & & \\
\hline & & & & & & & & & & & & & & \\
\hline & & & & & & & & & & & & & & \\
\hline & & & & & & & & & & & & & & \\
\hline & & & & & & & & & & & & & & \\
\hline
\end{tabular}

Onde: $\mathrm{CAP}=$ circunferência à altura do peito 
Anexo C- Distribuição dos gêneros da arborização viária da Estância de Águas de São Pedro-SP

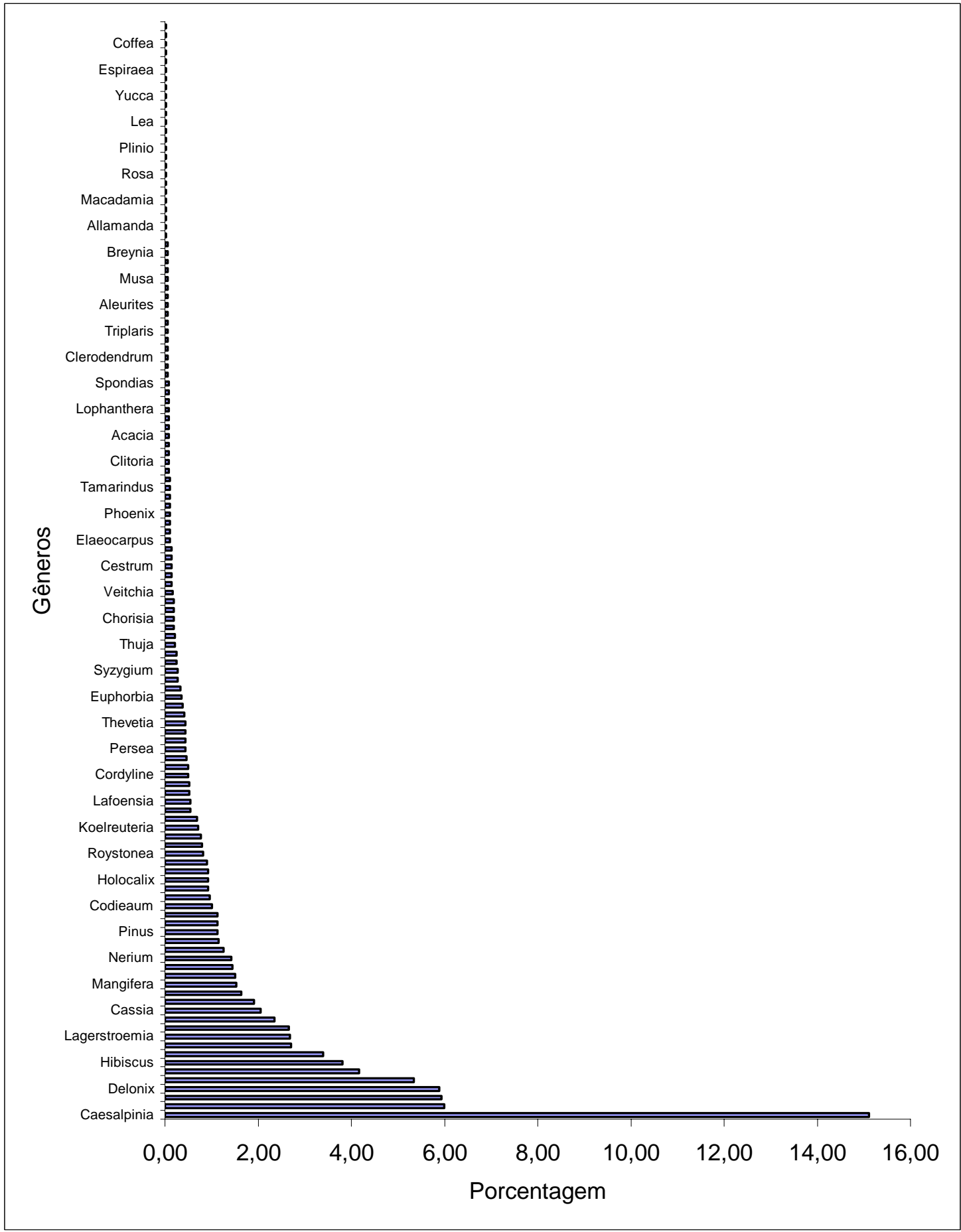


Anexo D- Distribuição das famílias da arborização viária da Estância de Águas de São Pedro-SP

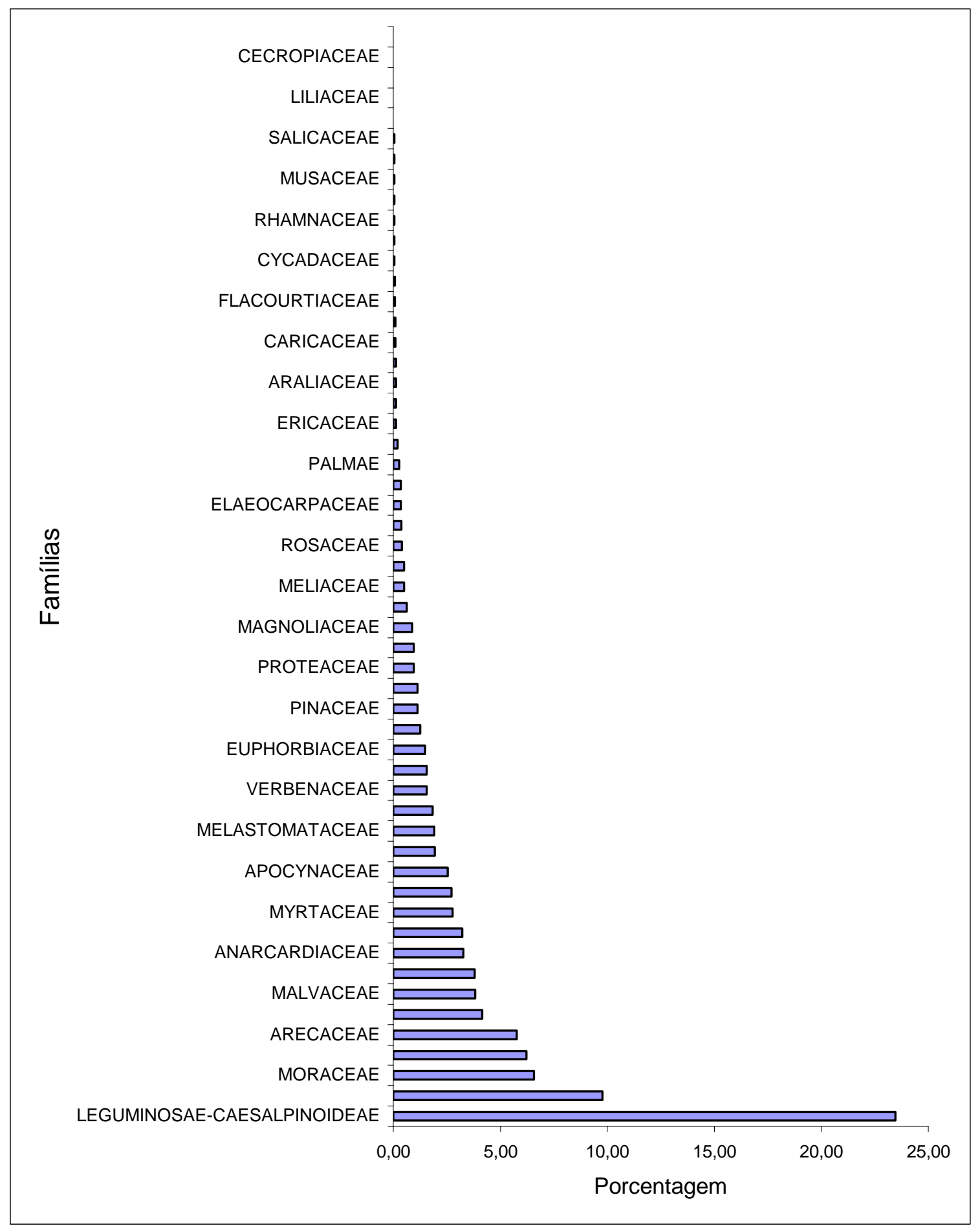




\section{REFERÊNCIAS BIBLIOGRAFICAS}

ÁGUAS DE SÃO PEDRO. Prefeitura Municipal. Secretaria de Desenvolvimento e Meio Ambiente. Águas de São Pedro. Águas de São Pedro, 2001. 18p.

ÁGUAS DE SÃO PEDRO. www.aguasdesaopedro.sp.gov.br (15 mar. 2004).

ALVAREZ, I.A.; LIMA, A.M.L.P.; FREIRE, H.B.; RIBEIRO, R.C.S. Desempenho ecológico: uma proposta para a avaliação da vegetação urbana (compact disc). In: CONGRESSO BRASILEIRO DE ARBORIZAÇÃO URBANA, 7., Belém, 2003. Resumos. Belém: UFPA, 2003.

ALVES, C.X.F.; SOUSA, B.A.A. Plano de arborização urbana de Betim (compact disc). In: CONGRESSO BRASILEIRO DE ARBORIZAÇÃO URBANA, 7., Belém, 2003. Resumos. Belém: UFPA, 2003.

AMARAL， R.D.A.M.; BRAZOLIM， S.; LIMA， A.M.L.P.; BARILLARI, C.T. Ocorrência de organismos xilófagos em árvores de pau-brasil (compact disc). In: CONGRESSO BRASILEIRO DE ARBORIZAÇÃO URBANA, 7., Belém, 2003. Resumos. Belém: UFPA, 2003.

ANDRADE, T.O. Inventário e análise da arborização viária da Estância Turística de Campos de Jordão, SP. Piracicaba, 2002. 112p. Dissertação (Mestrado) - Escola Superior de Agricultura "Luiz de Queiroz", Universidade de São Paulo. 
BARCELOS, P.R.A. A poda da arborização urbana. In: SEMINÁRIO DE ARBORIZAÇÃO URBANA NO RIO DE JANEIRO, 1.,Rio de Janeiro, 1996. Coleção paisagismo. Rio de Janeiro: EBA, 1997. p.125-132.

BUSARELLO, O. Planejamento urbano e arborização. In: ENCONTRO NACIONAL SOBRE ARBORIZAÇÃO URBANA, 3., Curitiba, 1990. Curitiba: FUPEF, 1990. p.54-59.

CEREZO, F.L.B.; MARTINS, C.S. Poda e arborização urbana em Belo Horizonte. In: CONGRESSO BRASILEIRO DE ARBORIZAÇÃO URBANA, 2.; ENCONTRO NACIONAL SOBRE ARBORIZAÇÃO URBANA, 5., São Luiz, 1994. Anais. São Luiz: Sociedade Brasileira de Arborização Urbana, 1994. p.377-387.

COELHO, R.M.P. Fundamentos em ecologia. Porto Alegre: Artes Médicas Sul, 2000. $247 \mathrm{p}$.

COMPANHIA ENERGÉTICA DE MINAS GERAIS. Manual de arborização. Belo Horizonte, 2001. 40p.

COSTA, L.A.C.; HIGUCHI, N. Arborização de ruas de Manaus: avaliação qualitativa e quantitativa. Revista Árvore, v.23, n.2, p.223-232, 1999.

COUTO, H.T.Z. do. Métodos de amostragem para a avaliação de arvores de ruas. In: CONGRESSO BRASILEIRO DE ARBORIZAÇÃO URBANA, 2.; ENCONTRO NACIONAL SOBRE ARBORIZAÇÃO URBANA, 5., São Luiz, 1994. Anais. São Luiz: Sociedade Brasileira de Arborização Urbana, 1994. p.169-179.

DEMÉTRIO, V.A.; CHADDAD, J.; LIMA, A.M.L.P.; CHADDAD JÚNIOR, J. Curso de composição de parques e jardins. Piracicaba: ESALQ, 1997. 82p. 
ELETROPAULO. Guia de planejamento e manejo da arborização urbana. São Paulo: Eletropaulo; CESP; CPFL, 1995. 38p.

EMPRESA BRASILEIRA DE TURISMO. Como valorizar nosso patrimônio para melhorar o turismo, passado um presente para 0 futuro. http: www.pdturismo.ufsj.edu.br/pesquisa/paspresfuturo .shtml. (30 abr.2004).

FARHAT, C.B.; MARÓSTICA, L.M.F. O planejamento urbano levando em consideração a arborização e as áreas verdes- Experiências de Maringá-PR. In: CONGRESSO BRASILEIRO DE ARBORIZAÇÃO URBANA, 2.; ENCONTRO NACIONAL SOBRE ARBORIZAÇÃO URBANA, 5., São Luiz, 1994. Anais. São Luiz: Sociedade Brasileira de Arborização Urbana, 1994. p.103-112.

FIRKOWSKI, C. Poluição atmosférica e a arborização urbana. In: ENCONTRO NACIONAL SOBRE ARBORIZAÇÃO URBANA, 3., Curitiba, 1990. Curitiba: FUPEF, 1990. p.14-26.

FORMAN, R.T.T.; GODRON, M. Landscape ecology. New York: Wiley,1986. 619p.

FREIRE, F.J.; LIMA, R.F.; SILVA, C.P. da; LEITE, A.C.M.P. Cadastramento das árvores públicas da cidade do Recife utilizando o sistema de informações geográficas (GIS). In: CONGRESSO BRASILEIRO DE ARBORIZAÇÃO URBANA, 2.; ENCONTRO NACIONAL SOBRE ARBORIZAÇÃO URBANA, 5., São Luiz, 1994. Anais. São Luiz: Sociedade Brasileira de Arborização Urbana, 1994. p.431-436.

GRENHA, R. O ensino da arborização urbana na escola de Agronomia da UFRRJ. In: SEMINÁRIO DE ARBORIZAÇÃO URBANA NO RIO DE JANEIRO, 1., Rio de Janeiro, 1996. Coleção paisagismo. Rio de Janeiro: EBA, 1997. p.145-152. 
HEILER, G.M. Trees and human confort in áreas. Journal of Forestry, v.72, n.8, p.462-469, 1974.

JORNAL NIPPO - BRASIL. Caderno Zashi Turismo. Maringá: os encantos da "Cidade Verde". http: www.nippobrasil.com.br/3.turismo.br/168.shtml. (3 maio 2004).

KIRCHNER, F.F.; DETZEL, V.A.; MITISHITA, E.A. Mapeamento da vegetação urbana. In: ENCONTRO NACIONAL SOBRE ARBORIZAÇÃO URBANA, 3., Curitiba, 1990. Curitiba: FUPEF, 1990. p.72-85.

KUGUIMIYA, E. Redes elétricas aéreas e subterrâneas- relação custo/benefício. In: CONGRESSO BRASILEIRO DE ARBORIZAÇÃO URBANA, 2.; ENCONTRO NACIONAL SOBRE ARBORIZAÇÃO URBANA, 5., São Luiz, 1994. Anais. São Luiz: Sociedade Brasileira de Arborização Urbana, 1994. p.113-120.

LIMA, A.M.L. Análise da arborização viária na área central e em seu entorno. Piracicaba, 1993. 238p. Tese (Doutorado) - Escola Superior de Agricultura "Luiz de Queiroz", Universidade de São Paulo.

LIMA, A.M.L.P.; COUTO, H.T.Z. do; ROXO, J.L.C. Análise das espécies mais freqüêntes da arborização viária, na zona urban central do município de PiracicabaSP. In: CONGRESSO BRASILEIRO DE ARBORIZAÇÃO URBANA, 2.; ENCONTRO NACIONAL SOBRE ARBORIZAÇÃO URBANA, 5., São Luiz, 1994. Anais. São Luiz: Sociedade Brasileira de Arborização Urbana, 1994. p.555578.

LOMBARDO, M.A. Vegetação e clima. In: ENCONTRO NACIONAL SOBRE ARBORIZAÇÃO URBANA, 3., Curitiba, 1990. Curitiba: FUPEF, 1990. p.1-13. 
LORENZI, H. Árvores brasileiras: manual de identificação e cultivo de plantas arbóreas do Brasil. 4.ed. Nova Odessa: Instituto Plantarum, 2002a. v.1, 384p.

LORENZI, H. Árvores brasileiras: manual de identificação e cultivo de plantas arbóreas do Brasil. 2.ed. Nova Odessa: Instituto Plantarum, 2002b. v.2, 384p.

LORENZI, H.; SOUZA, H.M. de.; TORRES, M.A.V.; BACHER, L.B. Árvores exóticas no Brasil: madeiras, ornamentais e aromáticas. Nova Odessa: Instituto Plantarum, 2003. v.1, 368p.

LORENZI, H.; SOUZA, H.M. de. Plantas ornamentais: arbustivas, herbáceas e trepadeiras. 3.ed. Nova Odessa: Instituto Plantarum, 2001. 1088p.

MACEDO, S.S. Quadro do paisagismo no Brasil. São Paulo: EDUSP, 1999. 144p. (Coleção Quapá, 1).

MACEDO, S.S.; SAKATA, F.G. Parques urbanos no Brasil. São Paulo: EDUSP, 2002. 207p. (Coleção Quapá).

MALAVASI, U.C.; AGUIAR SOBRINHO, J.; GAMA, L.L.M.F. da; ANDRADE, A.G. de; ROCHA, A.R. da. Inventário e recomendações para a arborização urbana na sede do município de Itaguaí-RJ. In: CONGRESSO BRASILEIRO DE ARBORIZAÇÃO URBANA, 2.; ENCONTRO NACIONAL SOBRE ARBORIZAÇÃO URBANA, 5., São Luiz, 1994. Anais. São Luiz: Sociedade Brasileira de Arborização Urbana, 1994. p.533-537.

MENDEZ, J.M.D. Considerações especiais sobre administração de turismo ambiental ou ecoturismo. In: ENCONTRO PARA CONSERVAÇÃO DA NATUREZA, 1. Viçosa, 1997. Anais. Viçosa: UFV, 1997. p.181-187. 
MENEGUETTI, G.I.P. Estudo de dois métodos de amostragem para inventário da arborização de ruas dos bairros da orla marítima do município de Santos-SP. Piracicaba, 2003. 100p. Dissertação (Mestrado) - Escola Superior de Agricultura "Luiz de Queiroz", Universidade de São Paulo.

MICCHI.S.M.P.; COUTO, H.T.Z. do Estudo de dois métodos de amostragem de árvores de rua na cidade de Piracicaba-SP. In: CONGRESSO BRASILEIRO DE ARBORIZAÇÃO URBANA, 3., Salvador, 1996. Anais. Salvador: Promoção SBAU, 1996. p.89-96.

MILANO, M.S. Métodos de amostragem para a avaliação de arborização de ruas. In: CONGRESSO BRASILEIRO DE ARBORIZAÇÃO URBANA, 2.; ENCONTRO NACIONAL SOBRE ARBORIZAÇÃO URBANA, 5., São Luiz, 1994. Anais. São Luiz: Sociedade Brasileira de Arborização Urbana, 1994. p.163-168.

MILANO, M.S.; DALCIN, E. Arborização de vias públicas. Rio de Janeiro: Light, 2000. 206p.

MONICO, I.M. Árvores e arborização urbana na cidade de Piracicaba/SP um olhar sobre a questão à luz da educação ambiental. Piracicaba, 2001. 165p. Dissertação (Mestrado) - Escola Superior de Agricultura "Luiz de Queiroz", Universidade de São Paulo.

MOTTA, G.L.O. Inventário da arborização urbana. Ação Ambiental: Arborização Urbana, v.2, n.9, p.11-13, 2000.

NEGRI NETO, A.N. Estimativa de demanda em turismo ecológico: um caso hipotético. Informações Econômicas, v.33, n.9, p.70-73, set.2003. 
NOWAK, D.J.; ROWNTREE, R.A.; MCPHERSON, E.G.; SISINNI, S.M.; KERKMANN, E.R.; STEVENS, J.C. Measuring and analyzing urban tree cover. Landscape and Urban Planning. v.36, p.49-57, 1996.

OLIVEIRA, F.B.; KAPPEL, R.B. Incidência de erva-de-passarinho na arborização de ruas em Porto Alegre. In: CONGRESSO BRASILEIRO DE ARBORIZAÇÃO URBANA, 2.; ENCONTRO NACIONAL SOBRE ARBORIZAÇÃO URBANA, 5., São Luiz, 1994. Anais. São Luiz: Sociedade Brasileira de Arborização Urbana, 1994. p.335-346.

PAIVA, H.N. de; GONÇALVES, W. Florestas urbanas: planejamento para melhoria da qualidade de vida. Viçosa: Aprenda Fácil, 2002. 177p. (Série Arborização Urbana, 2).

PEPER, P.J.; MCPHERSON, E.G.; MORI, S.M. Equation for predicting diameter, height, crown width, and leaf area of San Joaquim Valley street trees. Journal of Arboriculture, v.27, n.6, p.306-317, 2001.

PEREIRA, A.O. Parque dos lagos. Turismo no espaço rural brasileiro. In: CONGRESSO BRASILEIRO DE TURISMO RURAL: turismo no espaço rural brasileiro, Piracicaba, 1999. Anais. Piracicaba: FEALQ, 1999. p.120-124.

PORTO ALEGRE. Secretaria Municipal do Meio Ambiente. Equipe do Plano Diretor de Arborização Urbana. Cartilha da arborização urbana. Porto Alegre, 2002. 36p.

RACHID, C. Estudo da eficiência de dois métodos de amostragem de árvores de rua na cidade de São Carlos - SP. Piracicaba, 1999. 99p. Dissertação (Mestrado) - Escola Superior de Agricultura "Luiz de Queiroz", Universidade de São Paulo. 
ROBBA, F.; MACEDO, S.S. Praças brasileiras. São Paulo: EDUSP, 2002. 311p. (Coleção Quapá).

RODRIGUES, M.G.R.; BREDT, A.; UIEDA, W. Arborização de Brasília, Distrito Federal, e possíveis fontes de alimentos para morcegos fitófagos. In: CONGRESSO BRASILEIRO DE ARBORIZAÇÃO URBANA, 2.; ENCONTRO NACIONAL SOBRE ARBORIZAÇÃO URBANA, 5., São Luiz, 1994. Anais. São Luiz: Sociedade Brasileira de Arborização Urbana, 1994. p.311-318.

ROSO, A.L. Influência do sistema radicular de árvores urbanas na pavimentação em vias públicas. In: CONGRESSO BRASILEIRO DE ARBORIZAÇÃO URBANA, 2.; ENCONTRO NACIONAL SOBRE ARBORIZAÇÃO URBANA, 5., São Luiz, 1994. Anais. São Luiz: Sociedade Brasileira de Arborização Urbana, 1994. p.347352.

SANTAMOUR JÚNIOR, F.S. Trees for urban planting: diversity unifomuty, and common sense. Washington: U.S. National Arboretum, Agriculture Research Service, 2002.

SANTOS, E. de. Caracterização dendrológica e estética de 18 espécies arbóreas com potencial de uso em paisagismo e arborização urbana. Viçosa, 1994. 146p. Dissertação (Mestrado) - Universidade Federal de Viçosa.

SANTOS, N.R.Z dos; TEIXEIRA, I.F. Arborização de vias públicas: ambiente x vegetação. Santa Cruz do Sul: Instituto Souza Cruz, 2001. 135p.

SÃO PAULO (Estado). Secretaria do Meio Ambiente. Manual ambiental: princípios da recuperação vegetal de áreas degradadas. São Paulo: SMA;CEAM;CINP, 2000. $76 \mathrm{p}$. 
SÃO PAULO (São Paulo). Secretaria Municipal do Verde e do Meio Ambiente. Manual técnico de arborização urbana. São Paulo, 2002. 44p.

SEGAWA, H. Ao amor do público: jardins do Brasil. São Paulo: Studio Nobel, 1996. 240 p.

SERRANO, C.M.T. Uma introdução à discussão sobre turismo, cultura e ambiente. In: BRUHNS, H.T. (Org.). Viagens à natureza: Turismo, cultura e ambiente. 2.ed. Campinas: Papirus, 1999. p.11-25. (Coleção Turismo).

SILVA, A.G. da. Avaliação da arborização no perímetro urbano de Cajuri-MG, pelo método do quadro sintético. Viçosa, 2000. 150p. Dissertação (Mestrado) Universidade Federal de Viçosa.

SILVA, A.G.; GONÇALVES, W.; LEITE, H.G.; MARTINS, S.V. Avaliação comparativa de três métodos de obtenção de dados para avaliação da qualidade da arborização viária (compact disc). In: CONGRESSO BRASILEIRO DE ARBORIZAÇÃO URBANA, 7., Belém, 2003. Resumos. Belém: UFPA, 2003.

SILVA FILHO, D.F. da. Cadastramento informatizado, sistematização e análise da arborização das vias públicas da área urbana do município de Jaboticabal, SP. Jaboticabal, 2002. 81p. Dissertação (Mestrado) - Faculdade de Ciências Agrárias e Veterinárias, Universidade Estadual Paulista “Júlio de Mesquita Filho".

SILVA FILHO, D.F. da; PIZETTA, P.U.C.; ALMEIDA, J.B.S.A. de; PIVETTA, K.F.L.; FERRAUDO, A.S. Banco de dados relacional para cadastro, avaliação e manejo da arborização em vias públicas. Revista Árvore, v.26, n.5.p.629-642, 2002. 
SIMPSON, J.R.; MCPHERSON, E.G. Potencial of tree shade for reduzing residential energy use in California. Journal of Arboriculture, v.22, n.1, p.10-18. Jan.1996.

SOARES, M.P. Verdes urbanos e rurais: orientação para arborização de cidades e sítios campesinos. Porto Alegre: Cinco Continentes, 1998. 242p.

TEIXEIRA, R.C.; TEIXEIRA, I.S. A busca pela auto sustentabilidade do patrimônio histórico urbano. http: revistaturismo.cidadeinternet.com.br/artigos/ autosustentabilidade.html. (4 maio 2004).

TERRA, C.G. O jardim no Brasil no século XIX: Glaziou revisitado. 2. ed. Rio de Janeiro: EBA;UFRJ, 2000. 166p.

TRINDADE, J.A.da A importância histórico-cultural da arborização urbana na cidade do Rio de Janeiro. In: SEMINÁRIO DE ARBORIZAÇÃO URBANA NO RIO DE JANEIRO, 1., Rio de Janeiro, 1996. Coleção paisagismo. Rio de Janeiro: EBA; UFRJ, 1997. p.19-27.

VELASCO, G.D.N. Arborização viária X sistemas de distribuição de energia elétrica: avaliação dos custos, estudo das podas e levantamento de problemas fitotécnicos. Piracicaba, 2003. 94p. Dissertação (Mestrado) - Escola Superior de Agricultura “Luiz de Queiroz”, Universidade de São Paulo. 